\title{
Doctoral dissertations in human geography from Swedish universities 1884-2015: demographics, formats and productivity
}

DOI:

10.1080/03098265.2018.1436535

\section{Document Version}

Accepted author manuscript

Link to publication record in Manchester Research Explorer

Citation for published version (APA):

Niedomysl, T., Prowse, M., \& Lund Hansen, A. (2018). Doctoral dissertations in human geography from Swedish universities 1884-2015: demographics, formats and productivity. Journal of Geography in Higher Education, 42(3), 337-355. https://doi.org/10.1080/03098265.2018.1436535

\section{Published in:}

Journal of Geography in Higher Education

\section{Citing this paper}

Please note that where the full-text provided on Manchester Research Explorer is the Author Accepted Manuscript or Proof version this may differ from the final Published version. If citing, it is advised that you check and use the publisher's definitive version.

\section{General rights}

Copyright and moral rights for the publications made accessible in the Research Explorer are retained by the authors and/or other copyright owners and it is a condition of accessing publications that users recognise and abide by the legal requirements associated with these rights.

\section{Takedown policy}

If you believe that this document breaches copyright please refer to the University of Manchester's Takedown Procedures [http://man.ac.uk/04Y6Bo] or contact uml.scholarlycommunications@manchester.ac.uk providing relevant details, so we can investigate your claim.

\section{OPEN ACCESS}




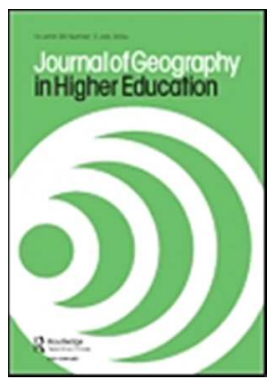

\section{Doctoral Dissertations in Human Geography from Swedish Universities 1884-2015: demographics, formats and productivity}

\begin{tabular}{|r|l|}
\hline Journal: & Journal of Geography in Higher Education \\
\hline Manuscript ID & CJGH-2017-0055.R1 \\
\hline Manuscript Type: & Research Paper \\
\hline Keywords: & $\begin{array}{l}\text { postgraduate education, doctoral dissertations, demographics, history of } \\
\text { geography, Sweden }\end{array}$ \\
\hline
\end{tabular}

\section{SCHOLARONE}

Manuscripts 


\section{DOCTORAL DISSERTATIONS IN HUMAN GEOGRAPHY FROM}

SWEDISH UNIVERSITIES 1884-2015: DEMOGRAPHICS, FORMATS

AND PRODUCTIVITY

\section{INTRODUCTION}

The development of human geography as a discipline is usually told with reference to its most prominent scholars and ideas (see e.g. Johnston \& Sidaway, 2015; Martin, 2015). While there is no doubt of the great value of such accounts, such overviews can only convey glimpses of the research carried out in the discipline. This paper seeks to contribute to the understanding of the development of the discipline from a different angle, that of doctoral dissertations. For most scholars, the doctoral dissertation is a career-defining piece of work, often the most important individual piece of research carried out and completed. As such it plays an important role not only for the individual scholar but more generally for knowledge production. It is, moreover, a key component of postgraduate education. In most countries, however, overviews of dissertations are not available (but see Kaplan \& Mapes, 2015, for a recent exception from the United States). This obstructs fruitful discussion on the development of the discipline.

The aim of this paper is to provide an exploratory overview of all doctoral dissertations in human geography published in Sweden. In addition to surveying the general trend over time for universities conferring doctoral degrees $1884-2015$, we pay specific attention to, first, the basic demographic characteristics of the authors (gender and age), and second, different formats of dissertations (monograph versus compilation). Third, for recent dissertations, we also explore author productivity through using a points system which combines the number of papers in a compilation dissertation, while taking into account co-authorship. 
Our first focus, on demographics, aims to contribute to discussions about gender-bias in the discipline. While it is well known that human geography has a history of gender bias (see McDowell, 1992; Massey, 1994), a recent study from the United States (Kaplan \& Mapes, 2016) showed that the share of women completing doctorates in geography has increased dramatically during the last few decades. Kaplan \& Mapes (2016) highlight two main types of research into gender bias within the wider discipline of geography in the US: the first uses biographical and life history data to understand the lived experiences of women who were pioneers within the discipline; the second uses secondary data alongside some forms of qualitative enquiry to examine levels of exclusion and associated reasons. Our contribution here which relies on quantitative analysis reflects the second of these two approaches and is a first step towards subsequent qualitative enquiry which will investigate explanations for the patterns reported here. A further component of our interest in demographics is the author's age at the time of publication. Reforms of postgraduate education have long aimed at reducing the time it takes for postgraduates to receive their doctorates (see e.g. Swedish Research Council, 2006). Such reforms have been striving to transform doctorates into a "driver's license" for research rather than a life's work (Gren, 2005). As far as we know, there are no international studies on the age of $\mathrm{PhDs}$ in the discipline.

Our second focus, which seeks to survey the most basic characteristics of dissertations, is due to broad interest in changes in dissertation format. Recent decades have seen the emergence of a new form of doctoral dissertation in many Scandinavian universities and elsewhere. The traditional route through which a doctoral student joined an academic epistemic and discursive community was through demonstrating an addition to knowledge in the form of a monograph, a single tome consisting of around $60,000-80,000$ words where an overarching 
research question was examined in an exhaustive and comprehensive manner. This traditional route to joining the academy remains more or less sacrosanct in most countries (Lee, 2010). But since the 1960s in Sweden, the PhD monograph has been challenged by a new dissertation format: the compilation dissertation (sometimes referred to as ' $\mathrm{PhD}$ by publication'). Here, a number of discrete articles in various stages of formation and publication are bound together with common themes, red threads and major contributions explained in an overarching summary (this summary is referred to as kappa in Swedish, i.e. cloak). We believe this is the first study to explore trends in dissertation formats for an entire country. We conduct a logistic regression on dissertations since 1964 to assess if the likelihood of completing this format varies systematically with demographic or institutional factors.

Our third focus, on author productivity, focuses solely on compilation dissertations. The recent emergence of compilation dissertations appears to be debated at most institutions, with questions raised regarding how many papers should be included, to what extent co-authorship should be allowed, how to measure the quality of journals and whether the papers have to be published or submitted for publication. These questions not only have implications for maintaining similar quality standards across institutions, but also for the careers of postgraduate students and supervisors (Jackson, 2013; Pretorius, 2017). Surprisingly, there are no formal minimum requirements for a compilation dissertation apart from the general guidelines we report in Section 2. We believe this is the first paper to investigate author productivity empirically. We use a simple proxy for the productivity of $\mathrm{PhD}$ students completing this form of dissertation by assigning points, 1 point for each paper, divided by the number of authors, for all the papers in the dissertation. We fully recognize this is a blunt proxy: it does not take into account first authorship nor the relative contributions of authors. 
Nevertheless, by using this proxy as a dependent variable, we are able to make modest claims about the extent to which demographic and institutional variables show a significant relationship with author productivity within the discipline.

The remainder of the article is structured as follows. The next section (2) discusses postgraduate education in Sweden and recent international debates focusing on compilation dissertations. The data collected and associated methods are discussed in Section 3. The results/discussion section (4) presents descriptive statistics, modelling outcomes and a full discussion of the implications of the findings. Section 6 concludes.

\section{RESEARCH CONTEXT}

The history of Swedish human geography has been portrayed in a number of studies (see e.g. Hägerstrand \& Buttimer, 1988; Helmfrid, 1999; Buttimer \& Mels, 2006). As Asheim (1987) notes, at least since the definitive break with descriptive, regional geography in the 1950s, and the location of departments within social science faculties, Swedish human geography has had a high profile internationally. However, there is surprisingly little research carried out that explicitly focusses on postgraduate education and doctoral dissertations in the discipline. The work of Gren (2005) is an exception that discusses the recent transformation of postgraduate education within human geography. Doctoral education is both a product of, and a contribution to, the production and reproduction of "the university's core practices: research, education and outreach/engagement" (Elmgren et al., 2016:87). At its core, this highest form of education builds on the Western learning ideal of Platonic paideia; an ideal that honours both practical and subject-based learning and a form of socialization of individuals in relation to the surrounding society (Thomson, 2001). To provide the reader with a background to contemporary postgraduate education and doctoral dissertations in Sweden, it is important to 
explain that throughout most of the discipline's history the path to the doctorate was considerably less structured than it is today. It used to be relatively easy for those inclined to be enrolled as doctoral students to attend seminars and obtain at least some supervision from senior scholars. However, little financial support was provided and faculty funding was usually reserved for those that were close to the degree. This meant it generally took a lot of time to complete a doctorate. It also appears to have been largely up to doctoral students to figure out what was required of them (Gren, 2005).

The extent to which this relatively unstructured approach to doctoral education in Swedish human geography had a strong gender dimension is not clearly delineated in the literature. Kaplan \& Mapes (2016) show that during the 1950s-1970s in the US only about 5 to 10 percent of the doctorates in geography were written by women, but by 2012 , this share had increased to 45 percent. Whilst observational evidence suggests a similar rise in Sweden at this time, thus far there is little empirical evidence to support this assertion. Sweden is arguably of particular interest since it is widely held to be one of the most gender-equal countries (see e.g. United Nations, 2015; World Economic Forum, 2015) and policymakers have actively promoted gender equality in universities (see e.g. SOU 2011:1).

Since the late 1990s Swedish postgraduate education in human geography has become much more structured and consists of four years of full-time study. To be accepted, students are required to hold a bachelor's degree in the disciple and often a master's degree. During these four years, students undertake temporary full-time employment at an internationally competitive level and may extend their studies for one additional year if they carry out teaching or perform administrative tasks in their department. Postgraduates spend about two thirds of their time working on their dissertations and about one third is devoted to courses 
(although this varies slightly across departments). Normally, a few courses are mandatory (typically in the philosophy of social science and on methodology) and are offered at departments, faculties or universities. There are also two to three annual national courses on various topics that are open to postgraduates from all human geography departments in Sweden.

Formally, the Swedish Higher Education Ordinance (SFS 1993:100) states that for a doctorate to be awarded the student must complete 240 educational credits, demonstrate broad knowledge of their chosen research field and recent, deep specialized knowledge on their chosen research questions. Moreover, a doctoral candidate must demonstrate the ability to critically review, assess and analyse new and complex phenomena independently through the choice of appropriate methods, make a contribution to knowledge and communicate this in national and international settings verbally and in writing. Further requirements are made in terms of contributing to responsible societal learning and ethics.

Considering these requirements, the growing popularity of a compilation dissertation appears to be related to the opportunities it offers postgraduate students to contribute more directly to international research and to obtain feedback from reviewers who are experts in their respective fields. As such, the review process complements, or possibly replaces, the seminars where doctoral students used to present and obtain feedback on the chapters of their coming monograph. It has also been argued that one of the main reasons behind the increasing popularity of compilation dissertations is a 'publish or perish' culture within universities (see Jackson, 2013; Pretorius, 2017) and the greater pressures academic staff are now subject to across Europe. Elmgren et al., (2016) argue that in the European policy context, the postgraduate education primarily serves the purpose of strengthening Europe's position in the 
global knowledge economy. The role of the universities is thus to produce the (creative) knowledge and human input to the contemporary "creative economy" (Peck, 2005).

Despite these trends and the associated lurch towards compilation dissertations, institutional guidelines and policies appear to be limited (Dowling et al., 2012; Jackson, 2013; Sharmini et al., 2015; Pretorius, 2017). In her review of Australian policy, Jackson (2013) found considerable variation across universities regarding the number and type of papers within a compilation dissertation and associated co-authorship guidelines. Whilst Jackson (2013) emphasizes that there are significant benefits in compilation dissertations, both for postgraduate students and supervisors, there appears to be insufficient guidance on the quantity and quality of publications as well as problems with how to evaluate such dissertations compared to the traditional monograph. Sharmini et al., (2015) also highlight how many examiners, although generally positive towards compilation dissertations, are concerned about the individual contribution of a doctoral candidate when co-authoring in terms of their individual intellectual contribution. It can be argued that the lack of a policy debate on what constitutes an adequate compilation dissertation is partly determined by a lack of data which limits the depth of discussion when comparing dissertation types and improving existing policies and legislation. We now turn to the unique dataset we utilize to try to contribute to the growing debate in a number of countries (Jackson, 2013; Sharmini et al., 2015).

\section{DATA AND METHODS}

\subsection{Compiling a database of dissertations}

Our first task was to compile a database, a task which proved more time-consuming than anticipated and included numerous approaches to identifying potential cases. First, most 
departments present the title of the most recent dissertations produced on their website or through a publication series. Second, library search engines and Internet sites (such as www.avhandlingar.se and www.libris.kb.se) also allowed the identification of dissertations. Third, a departmental survey carried out as part of a national evaluation of postgraduate studies by the Swedish National Agency for Higher Education (2006) provided the titles of all doctoral dissertations published 1970-2004. Fourth, prof. em. Gunnar Törnqvist kindly provided a literature list on doctoral dissertations from a reading course that was once held at Lund University. Fifth, a further source was Buttimer \& Mels (2006) who list dissertations in geography 1884-2000. By cross-examining these various sources it seems likely that all dissertations in the discipline produced in Sweden until 2015 have been identified, although it may be that one or two have gone undetected.

After compiling a list of all dissertations, theses were borrowed from libraries or downloaded from the Internet. We then excluded dissertations in physical geography, but maintained earlier regional studies which included substantial human geography content. This task was made by subjective assessment of the content but we also made use of earlier classifications of dissertations by Helmfrid (1999) and Buttimer \& Mels (2006). Finally, we only included dissertations that had been published by institutions with the right to award doctoral degrees in Human/Economic Geography (or similar wording). In Sweden, seven universities (Gothenburg, Karlstad, Lund, Stockholm, Umeå, Uppsala and Örebro) have the right to award 
[examensrätt] such a doctoral degree. ${ }^{1}$ This overview is restricted to only those dissertations produced at these universities. $^{2}$

One further issue was co-authorship as three dissertations had two authors (i.e. Järnegren \& Ventura, 1977; Lundmark \& Malmberg, 1988; Blom-Mondlande \& Jansund, 2003). Since the formal rules for a co-authored doctoral dissertation are that each author's contribution should be identifiable, we count a co-authored dissertation as two dissertations. Hence, in the empirical analyses, each author is considered to be a sole author of a dissertation, so these three dissertations are counted as six. This is appropriate as many compilation dissertations are also co-authored (see below).

\subsection{Demographic characteristics of authors}

The gender of each author was identified through first and surnames. In a few cases we relied on contacts with colleagues at the authors' departments to correctly identify the gender. As regards the author's age, we were able to identify the year of birth for the vast majority of authors by means of the National Library of Sweden (this was not possible in only 30 cases, primarily for the oldest dissertations).

\subsection{Format of dissertations}

A somewhat unexpected problem turned out to be classifying a dissertation as a monograph or a compilation. We learned that in a few cases (e.g. Helmfrid, 1962; Claeson, 1964) the entire text of the dissertation had been published as a single journal article of more than 100 pages

\footnotetext{
${ }^{1}$ Strictly speaking, Gothenburg has the right to award a doctoral degree in economic geography; Lund University in human geography/economic geography and Stockholm University in geography "with specialization in Human Geography". For further discussion about the relevant institutions see Helmfrid (1999).

${ }^{2}$ Doctoral dissertations produced at other universities (e.g. at KTH Royal Institute of Technology and at Linköping University) could have been included had those universities had the right to award a doctoral degree in human geography.
} 
(which appears to have been a cost-saving strategy as postgraduate students used to be responsible for the costs of printing). We decided that such dissertations should be classified as monographs. Finally, we also found that the language varied in a few compilation dissertations (e.g. Hallencreutz, 2002) where some papers had been written in Swedish and others in English. In those cases, we decided that the language of the summary (kappa) should determine the classification.

\subsection{Author productivity}

Needless to say, author productivity is a difficult facet to quantify in a dataset. Our approach in this paper is to use a simple points-based system that is used informally at some university departments in Sweden. This aims to provide a crude measure of the independent productivity of authors of compilation dissertations. The informal system, referred to as the 3-points system, is that the score for each paper is 1 divided by the number of authors. In other words, a single-authored article by the $\mathrm{PhD}$ student is a 1 , an article with 2 authors is 0.5 , an article with 3 authors is 0.33 , and so on. These figures are then totalled for all the articles in the compilation dissertation. The guiding rule is that a total score of 3.0 (or higher) is an acceptable level to demonstrate independent productivity. Using this proxy, we assess the extent to which there are any significant differences in terms of author productivity across gender, age and university institution.

It should be emphasized that this is a blunt proxy since it does not take into account the quality of the papers, whether they are published in prestigious journals (or not published at all, although the general rule is that they should be of "publishable" quality), or whether they include empirically-collected data. Moreover, it assumes that all authors contributed equally to the work (and that all who made substantial contributions are acknowledged as co-authors). 
It is not possible to analyze the ordering of authors as an indicator of relative contributions since it seems that alphabetical ordering is still quite common. Finally, it needs to be recalled that postgraduate students have to take courses in addition to writing their dissertation. We do not control for this when estimating the determinants of author productivity (since there are only minor differences between the departments as regards the number of courses postgraduate students have to complete). Nor have we been able to control for the time it takes for postgraduate students to complete their doctoral degree.

\subsection{Methods of analysis}

The approach adopted in this paper is largely descriptive, focusing on providing a general overview of dissertations and their authors. However, we have also relied on multivariate analysis to explore the data further in two additional ways. First, to see the extent to which our demographic and institutional variables had any relationship with the format of a dissertation. Specifically, whether gender, age or institution influenced the likelihood of producing a compilation dissertation (instead of a monograph) via a logistic regression on a restricted sample of dissertations produced since 1964 (this was the year when the first compilation dissertation was produced). Out of the 448 dissertations produced since 1964 (359 monographs and 89 compilations) we excluded dissertations from Gothenburg, Karlstad and Örebro in the regressions since they had too few compilation dissertations, leaving the final sample with 351 dissertations (268 monographs and 83 compilation dissertations). Dummy variables were created for the four institutions with a sufficient sample size: Lund, Stockholm, Umeå and Uppsala.

Second, we conducted an OLS regression to assess the extent to which the demographic and institutional variables had a relationship with author productivity, proxied by using the points 
system as explained above. The sample here was the 83 compilation dissertations. We transformed two variables (age and points were logged by 10) so that skewness and kurtosis were within safe limits. We also used dummies for key departments. We now turn to the results starting with the descriptive statistics.

\section{RESULTS AND DISCUSSION}

\subsection{General overview}

Figure 1 below shows the number of doctoral dissertations: 507 dissertations from 1884 to 2015. According to our investigation, the first doctoral dissertation to be published in the discipline at a Swedish university was written by Schwerin (1884) at Lund University. Evidently, in the early years progress was notably slow and it then took more than a decade before the next dissertations were published (by Ahlenius in 1895 and Lönborg in 1897, both at Uppsala University). In fact, 50 years after the first dissertation, only 14 more dissertations had been published (6 at Lund University, 6 at Uppsala University and 2 at Stockholm University). However, from 1936 and onwards, dissertations came out almost yearly and a notable increase occurred during the late 1960s. The 1960s and 1970s arguably represent a highpoint for the discipline, with significant societal impact during the construction of the welfare state. The number of dissertations has continued to be published in ever greater numbers (though not quite in a linear fashion). Between 2006 and 2010, a record number of 82 dissertations were produced.

\section{--- FIGURE 1 ABOUT HERE ---}

This rapid increase during the last few decades raises the question of whether this trend is unique to human geography or whether it simply reflects a general increase of doctoral 
dissertations in the social sciences. The Swedish Higher Education Authority (2016) publishes statistics on the total number of doctoral degrees awarded in the social sciences (by university) going back to 1973, which allows for a general comparison of the trend. Such a comparison shows that the share of dissertations in human geography account for 3.9 percent of the total social sciences during 1973 to 2014. The high- and low-points of 1977 (13.9 percent) and 1978 (1.0 percent) stand out as extreme values. Apart from those exceptions the general trend is clear and points to a diminishing share of dissertations in human geography compared with the rest of the social sciences. A linear trend line (not shown) starts at 6.0 percent in 1973 and ends at 2.6 percent in 2014. In terms of shares, then, this clearly suggests that the discipline is losing ground in comparison to other social science disciplines.

Our database also allows us to investigate the institutions where the dissertations were produced. Unsurprisingly, it turns out that the two oldest universities have been the most productive with Uppsala first, where 24 percent $(n=121)$ of the dissertations were published, closely followed by Lund with 23 percent $(n=119)$ and then Stockholm with 21 percent $(n=107)$. Combined, these three institutions account for more than two-thirds of the human geography dissertations in Sweden. Gothenburg University, where the first dissertation was published in 1936, ranks fourth with 75 dissertations (15 percent) and Umeå University (which attained university status in 1965) have produced 55 dissertations (11 percent). The two youngest universities Karlstad (1999) and Örebro (1999) have produced 21 and 9 dissertations (4 and 2 percent) respectively. While these figures are perhaps unsurprising, looking at the recent trends is quite revealing. Among the four largest universities, Uppsala, Stockholm and Gothenburg have had a stable share of dissertations since the late 1960s, whilst Lund is experiencing a noticeable downward trend. The younger institutions of Umeå, Karlstad and Örebro are now publishing a larger share. 


\subsection{Demographic characteristics of the authors}

An issue that has been given a lot of attention in academia in recent decades is the gender balance of faculty staff. As shown in Figure 2 below, a gender bias has existed in Swedish human geography during most of the discipline's history. In fact, during the first hundred years only 15 women published a doctoral dissertation, comprising a meagre 9 percent of the total. It took almost 80 years after the first woman, Anna Kristoffersson (1924), defended her dissertation in Lund before a noticeable change occurred during the 1990s. Whilst progress was slow in the first seventy years of the last century, it has been very dramatic since then.

\section{--- FIGURE 2 ABOUT HERE ---}

Indeed, since 2000 a majority (59 percent) of dissertations have been published by women. Whilst women appear to have broken through the glass ceiling at the doctoral level, we have not examined the gender balance in taught postgraduate education course (it might very well be that women constitute the majority of these students). Overall, the high number of women successfully defending doctorates shows that discussions about gender balance in the discipline need to be nuanced.

Turning to the age of authors, the trend was less distinct. While age appears to have increased quite steadily until 1956-1960, peaking at a mean age of 43, it then fell to 36 years in 19761980, increasing again to a mean age of 42 in 1991-1995, before falling again to about 36 years since 2001. Cross-tabulations of author age with other factors in the database only reveal that authors of compilation dissertations are almost four years younger on average than 
monograph authors. The general impression is of a rather stable age-profile in the discipline over time $($ Mean age =37, Min. =26; Max. =65; $\mathrm{Md}=36 ;$ Std. dev. $=6,8)$.

\subsection{Format of dissertations}

As can be seen from Figure 3 below, the vast majority of doctoral dissertations have been published as monographs $(\mathrm{N}=418,82$ percent). While a handful of compilation dissertations were published from 1965 to 2000 (the first by Bruno Johnsson at Stockholm university in 1965), from 2001 the proportion of compilation dissertations has increased markedly with this dissertation format now being as popular as a traditional monograph (in total 89 compilation dissertations have been published, constituting 18 percent of all doctoral dissertations).

\section{--- FIGURE 3 ABOUT HERE ---}

The popularity of compilation dissertations varies across institutions. This format is a rare phenomenon in Gothenburg and Karlstad (only 3 have been published in the former institution, 1 in the latter), but elsewhere it appears to have become a popular alternative to the traditional monograph. This is particularly the case in Umeå where 24 compilation dissertations have been published corresponding to a total share of 44 percent of all doctoral dissertations. The largest number of compilation dissertations have been published in Uppsala ( $\mathrm{N}=27$ corresponding to 22 percent of the total). The other two older universities Lund $(\mathrm{N}=17$, 14 percent $)$ and Stockholm $(\mathrm{N}=15,14$ percent $)$ have a similar share to each other.

Another major trend is evident: an increasing number of doctoral dissertations are published in English. Until the 1960s only a handful of dissertations were in English (only 2 percent of the total have been published in languages other than Swedish or English) and the vast 
majority chose to publish their dissertation in Swedish. During the 1960 s this started to change and since the 1990s about half of all dissertations have been published in English, reaching 74 percent in 2011-2015. To a large extent this increase is related to the growth of compilation dissertations (92 percent of which are published in English).

\subsubsection{Multivariate analyses of dissertation format}

As explained in section 3.5, we use a simple logistic regression model to see if any relationships could be detected between demographic and institutional variables and the probability of completing a compilation dissertation. The results are shown in Table 1 below in which the likelihood of publishing a compilation dissertation (as opposed to a monograph) has been estimated.

\section{--- TABLE 1 ABOUT HERE ---}

Model 1, with just gender in the model, is not significant and has no explanatory power over the choice of dissertation format. Model 2, with gender and age, is significant and explains 6$9 \%$ of the choice between a monograph and compilation dissertation with the odds of completing a compilation dissertation decreasing by 0.897 each unit of $\log ^{10}$ age. Model 3 is significant and as a whole explains $10-16 \%$ of the likelihood of completing a compilation dissertation. Holding other factors constant, the model shows two significant variables: age has a negative influence on the probability of completing a compilation dissertation; going to Umeå increases the probability, by a factor of 2.951. An interaction term with age/gender did not add anything to the model. We now turn to assessment of the independent productivity of the authors using only the restricted sample of compilation dissertations. 


\subsection{Author productivity}

The quality of papers included in compilation dissertations vary. Here, we have been forced to treat them all in the same way, only paying attention to the number of papers and the number of co-authors per paper. Table 2 below shows that there is quite a large difference across institutions in terms of the numbers of papers per dissertation, ranging from 2 to 8 with a median and mean figure of 4 . The exceptions are dissertations from Lund where the number of articles is higher (Mean 4.71) than other institutions (mean 4.14). Considerably more variance is found for the number of co-authored articles. Stockholm stands out with an average of 0.73 co-authored papers compared with Lund where the average is 2.24. Turning to the number of points, the lowest score of 1.16 and the highest score of 8.00 implies that author independence varies considerably. Among university institutions, Umeå stands out with the lowest average score.

Putting these findings together, Table 2 below suggests that when using the points system as a proxy, the most 'productive' dissertations have been from Uppsala, followed by Stockholm, Lund and finally Umeå (significant at the 95\% level). Interestingly, differences between institutions are not driven by the number of articles within a compilation dissertation (which is highest in Lund and lowest in Stockholm, significant at the $90 \%$ level) but by the degree of co-authorship of articles, presumably by supervisors, which is highest in Lund followed by Umeå (significant at the $99.9 \%$ level). This practice is least common in Stockholm. We can see that Lund's productivity in the number of articles is, in a sense, tempered by the high number of articles which are co-authored.

--- TABLE 2 ABOUT HERE --- 


\subsubsection{Multivariate analyses of author productivity}

We now turn to the multivariate model to isolate the influence of each factor in turn. To assess the factors that contribute to productivity as proxied by the points system, we conducted an OLS regression with the restricted sample of 83 units, the results from which are shown in Table 3. Including the number of articles and the number of co-authored articles as independent variables would mean the model transgressed two key requirements: no multicollinearity and the normal distribution of residuals. The model below displayed VIF figures for multicollinearity that are within safe limits and residuals are distributed normally.

\section{--- TABLE 3 ABOUT HERE ---}

Model 1, with just gender as an independent variable, shows how women candidates attain, on average, 0.42 more points than men (significant at the $95 \%$ level), with the model as a whole explaining 4\% of the variance in points. Adding age in Model 2 changes little. When we add institutional dummies in Model 3, Umeå emerges as significant at the 95\% level with, ceteris paribus, attendance at this university reducing the point score by 0.5 . At the same time, we can see that the gender dummy loses significance. As Model 3 explains only $7 \%$ of the variance in the dependent variable, the OLS regression highlights overall how author productivity (as proxied by points) from a compilation dissertation is influenced by unobservables, such as skills, supervisory expertise, supervisory involvement, not most of the independent demographic or institutional variables in the model.

Two findings jump out immediately from the analysis above: the significant recent increase in the number of compilation dissertations in the discipline and the better gender balance of completed doctorates in recent decades. We now discuss each in turn. 
Our findings show that for a small discipline such as human geography, there is significant variation in the prevalence of compilation dissertations across universities and that younger $\mathrm{PhD}$ students are preferring this format (see Table 2). This warrants further discussion. The rise of compilation dissertations is perhaps not that surprising when one considers the incentives for PhD students, departments and faculties. For example, Fridlund (2010) suggests it may be easier to fail the degree when completing a monograph as compilation dissertations (almost) always contain some published work which has been vetted by reviewers and an editor. Including published prose in a compilation dissertation therefore decreases the likelihood that an examiner will take a very negative stance. PhD students are also concerned about their career prospects in the labour market. Securing a position within academia depends partly on demonstrated ability to publish and to secure research funds (and to a lesser extent on the ability to teach well). In this respect, the production of published articles within a compilation dissertation increases the speed with which a $\mathrm{PhD}$ candidate will be considered for a university job (Lobell, 2012).

There is also a temporal issue here which deserves consideration. It may well be that publishing during a $\mathrm{PhD}$ can increase short-term job prospects but this is not to say the strategy bodes well for long-term careers within academia. Paré (2010) highlights how rushing students into publishing may not yield long-term benefits as researchers who have completed a compilation dissertation may struggle to attain the necessary independence and self-reliance to advance quickly within an academic environment. Indeed, such researchers may become path dependent on the article format and lack the experience and confidence to tackle monographs and edited volumes during their careers. 
Furthermore, Paré (2010) usefully highlights how supervisors also often have a significant interest in the production and completion of a compilation dissertation. As they often play the role of a silent second author of the dissertation, dependent on contextual norms, supervisors may remain invisible or, more commonly nowadays in the social sciences, co-author part of the dissertation in the form of journal articles. But whilst co-authorship may be beneficial for a supervisor in terms of status and possible promotion, there is a possibility it could hinder a doctoral candidate's own career if the student is unable to clearly explain their precise contribution to published articles. In some respects, supervisors who co-author articles with doctoral students are getting paid twice - once in terms of the in kind payment for the supervision process, and once in terms of status from fast publications. Overall, there is a considerable incentive here for supervisors to nudge students towards a compilation dissertation.

A broader point is that funding models within a faculty and university in Scandinavian countries at least partly rely on publication outputs. Those in leadership roles within departments and universities therefore have an incentive to encourage $\mathrm{PhDs}$ to complete compilation theses as the publication of articles during and not after the duration of a $\mathrm{PhD}$ brings extra resources to the institution's coffers. Highlighting the incentives at play in the choice of dissertation format for $\mathrm{PhD}$ students, supervisors, institutes and faculties is one element of the political economy of doctoral education: in other words, how actors and institutions in academia compete for and use resources and power in relation to doctoral students.

In addition to the points raised above, of particular relevance here is the issue of language: that the majority of international journals require manuscripts in English. Such a requirement 
offer a considerable advantage to 'native' English speakers, whether a supervisor or the doctoral candidate: the tacit knowledge and precision honed through socialization in an Anglophone environment allows an ease of expression easily detected by reviewers and editors. The barriers to entering the publishing 'community of practice' (Wenger, 1998) are therefore considerably higher for 'teams' without a 'native' speaker on board. As Canagarajah (2007) highlights, proficiency for these 'teams' is based on learning by doing and adaptation to the (often mixed) signals and message received from editors and reviewers. The choice of a compilation dissertation, often by younger candidates, brings doctoral candidates into linguistic 'contact zones' (Pratt, 1991) much sooner. Exclusion from these zones and 'communities of practice' for non-native speakers is exacerbated for scholars who, as Canagarajah (2002) highlights, need to learn to use discursive strategies to package articles in the necessary format for acceptance and publication (even if this detracts from the scientific rigour of the manuscript).

It is important to highlight at this stage that more than 70 percent of all dissertations are now published in English. While this trend clearly helps the internationalization of Swedish postgraduate students, little is known about whether this helps or possibly damages their careers. Moreover, whilst the incentives at different scales support the choice of a compilation thesis in Sweden when the linguistic barriers of diction and tone are overcome (which, we believe, also holds across Scandinavia more broadly), this choice may lead to a tension with the broader aims of the academy (in addition to teaching and pure research): to inform debate in the society (which largely finances the academy) through engaging in public discussions based on applied research. The hegemonic position of English as the lingua franca of academia alienates universities and their scholars (in the non-Anglophone world) from the citizens they are supposed to be supporting most directly. Swedish human geography has had 
a tradition of maintaining strong links with society. In a period of considerable societal change, the extent to which human geography can now contribute fully to current national and Scandinavian policy debates on urban planning, social cohesion, economic growth and inequality using the international lingua franca are currently unclear.

In addition, academia can often be depicted as aloof and distant: an elitist gown is often resented by people in town. Publishing in a foreign (albeit global) language, English, can only reinforce the separation from mainstream society. In this respect, there appears to be a contradiction between the incentives at the individual and institutional levels and the relationship the academy has (in the non-Anglophone world) with it's citizens. One consequence of this may well be a reversion amongst citizens (both close to universities and further afield) to what Bauman and Briggs (2000) refer to as the 'Herderian Triad' where language, community and place are seen as inseparable and insoluble. Here, English, the language of globalization and the movers who have explored the world as trade barriers and borders have dissolved in the past three decades, is seen not as a cosmopolitan medium to attain greater understanding of people and phenomenon but as a threat: it is the language of global elites and unwelcome immigrants (not just foreign students but economic migrants and refugees to boot).

This is not to say that the dominance of English-language journals is the only or even main influence on the apparent greater gulf between universities and society. The promotion of competition and use of the market mechanism within and between Scandinavian universities has had a significant impact on the relationships between universities, researchers/teachers, students and surrounding society. Such reforms within the university sector have contributed to a highly-specialized subdivision of knowledge, greater differentiation and specialization (as 
reflected in the number of newly-established scientific journals, Larsen and Von Ins, 2010) as well as an increasingly obsessive focus on outputs: patents, publications, prizes, citations, funding, finished students. Academics, departments and faculties are increasingly assessed in relation to these output measures. The extent to which this has impacted negatively on the tuition and training process for doctoral students is a pertinent question (Björkman, 2015) as well as the ability of university staff to engage deeply in debates in society at large.

Our second key finding is the dramatic increase in the number of women completing doctorates in the discipline. This is surprising for at least two reasons. First, the extreme gender inequality in the discipline before the millennium. Second, university policies (such as for recruitment for doctoral candidates) still emphasize the need for a better gender balance, which gives rise to the question of whether the fact that women now constitute a majority of completed doctoral dissertations has percolated through to university policy or not. One would expect that an equal gender balance within senior ranks (lecturers and professors) is close now there is a balanced cadre of candidates to choose among. One approach to theorising the better gender balance within doctoral candidates is to apply Kabeer's (1999) conceptualization of empowerment (which, inter alia, is influenced by Amartya Sen's entitlement approach) to this case.

Kabeer (1999) argues that gender empowerment can be understood as the ability to exercise strategic and transformatory choices (within the constraints of a contextual choice set) based on access to and control over resources (defined broadly as current and expected assets and entitlements) and agency (the ability to define goals and pursue them despite countervailing opposition) leading to achievements (outcomes). Kabeer (1999) stresses the importance of the contextual choice set from which individuals are or are not able to make and act upon choices 
(and refers to Bourdieu's, 1977, notion of doxa): that this choice set is predicated on existing (often unconscious and naturalised) norms and values within a society.

Applying this framework to the better gender balance within doctoral students in human geography appears fruitful. Within a context of active policies to promote gender equality within one of the most gender-equal countries in the world, since the millennium women in Sweden have successfully utilized their seemingly better academic grades at undergraduate and postgraduate levels and the networks fostered during their studies to enter and, importantly, complete doctoral studies in human geography. But the choice to apply for doctoral positions in the discipline (which, in part, is still imbued with the remnants of previous patriarchal approaches) is only the first step: selection onto a shortlist; being offered a doctoral post; navigating the mandatory educational requirements of the programme (and often some teaching/administration responsibilities); working with a supervisor or supervision team; producing drafts, chapters/articles; and successfully defending the dissertation are all part and parcel of a doctoral process. During this endurance test (for that is what doctoral studies often are), agency and doxa are intertwined: the ability to pursue the goal of a doctorate is conditioned by the value-laden choice set candidates face: prominent examples of flourishing academics who are women within similar departments, faculties and universities (as well as in broader society) may well have played as important a role as written policy statements and intentions. The implication of this may be that the rapid rise of women as successful doctoral candidates within the discipline in Sweden may be hard to replicate in countries, especially in the global South, where gender equality is less advanced and the doxa is undoubtedly different.

\section{CONCLUSIONS}


This paper has provided an overview of all doctoral dissertations in Swedish human geography between 1884-2015. The specific focus has been on describing the demographics of the authors (looking in particular at age and gender), the format of dissertations (monographs versus compilation dissertations) and on exploring productivity variations for authors of compilation dissertations. The overall results show that the number of doctoral dissertations in human geography has increased substantially during the last half century. However, the discipline is contributing a decreasing share of doctoral dissertations since the 1970s. In that light, the future of the discipline may not be as bright as at first glance.

In terms of demographics, we find evidence of both stability and change. First, the age of the authors remains relatively stable. Second, doctoral candidates have changed over time from being almost exclusively men to now having a better gender balance. Since 2000 a majority (59 percent) of dissertations have been published by women, which points to the need for a nuanced discussion about gender in the discipline.

Another notable trend is writing a compilation dissertation instead of a monograph, with the latter format nowadays accounting for less than half of all dissertations. This is quite a significant change and a departure from the traditional view of a doctoral thesis. Results show that being young university increases the likelihood of completing a compilation dissertation. Ongoing discussions in many institutions are a clear sign that the lurch towards compilation theses needs to be openly discussed in order to improve postgraduate education and the discipline.

The results further show that for those who publish their dissertation as a compilation author productivity is, for some reason, lower if attending Umeå University, and that age, gender and 
attending any of the other institutions (which have a reasonable number of compilation theses) does not have a significant impact on productivity. Our interpretation is that individual author productivity (at least when proxied by points for compilation dissertations) is mainly influenced by unobservables, possibly factors such as skills, supervisory expertise or supervisory involvement.

We believe this article is a first step towards investigating the rapid changes within the discipline in Sweden, changes which resonate with broader global themes (of gender equality and the use of English as the lingua franca within the academy) and changes which subsequent qualitative enquiry may be able offer convincing explanations for. The article has highlighted numerous avenues for further research. First, a comparison of the gendered completion rate for doctorates with the gender balance of tenured staff in departments. As a starting point, we made an attempt to investigate the academic careers of the 82 individuals that published their dissertation during the 1990s. Using the Internet and the authors' own knowledge, we were able to conclude that 27 percent of the men had made it to the rank of professor, but this share was even higher among females (36 percent). Further research is required here. Second, through reviewing the subjects of doctoral dissertations one could identify changes in the balance of sub fields within human geography. And third, to investigate the productivity of compilation dissertations through a more refined and more accurate metric (using journal impact factors or similar approaches) than the 'points' proxy we have used here. As a final remark, we hope that this research can inspire scholars to perform similar basic analyses of doctoral dissertations in other countries. It is the authors' firm belief that it is only through comparative research that the development of postgraduate education in human geography can be fully understood and subsequently improved. 


\section{REFERENCES}

Ahlenius, K. (1895). Olaus Magnus och hans framställning af Nordens geografi: studier $i$ geografins historia. Uppsala: Uppsala Universitet.

Asheim, B. T. (1987). A critical evaluation of postwar developments in human geography in Scandinavia. Progress in Human Geography, 11(3), 333-353.

Bauman, R. \& Briggs, C. L. (2000) 'Language Philosophy as Language Ideology: John Locke and Johann Gottfried Herder' in Kroskrity, P. V. (ed.) Regimes of language: Ideologies, polities, and identities. James Currey.

Björkman, J. (2015). Swedish Publications in a Global World. Culture Unbound: Journal of Current Cultural Research, 7(4), 576-587.

Blom-Mondlande, U. \& Jansund, B. (2003). Geografi-Didaktik-Praktik. Interaktiva studier av förloppslandskapet. Gothenburg: University of Gothenburg.

Bourdieu, P. (1977). Outline of a Theory of Practice. Cambridge: Cambridge University Press.

Buttimer, A. \& Mels, T. (2006). By northern lights: on the making of geography in Sweden. Burlington: Ashgate.

Canagarajah, A. S. (2003). A somewhat legitimate and very peripheral participation. In Casanave, C. P. \& Vandrick, S. (eds.) Writing for scholarly publication: Behind the scenes in language education. Routledge.

Canagarajah, A. S. (2007). Lingua franca English, multilingual communities, and language acquisition. The Modern Language Journal, 91(1), 923-939. 
Dowling, R., Gorman-Murray, A., Power, E. \& Luzia, K. (2012). Critical reflections on doctoral research and supervision in Human Geography: the 'PhD by publication'. Journal of Geography in Higher Education, 36(2), 293-305.

Claeson, C. F. (1964). En korologisk publikanalys framställning av demografiska gravitations modeller med tillämpning vid omlandsbestämning på koordinatkarta. Geografiska Annaler, $46(1)$.

Elmgren, M., Forsberg, E., Lindberg-Sand, A. \& Sonesson, A. (2016). The formation of doctoral education. Lund: Lund University.

Fridlund, B. (2010). The dissertation book; Should it be a monograph or a compilation thesis? European Journal of Cardiovascular Nursing, 9(3): 144-145.

Gren, M. (2005). Forskarutbildning i kulturgeografi. Karlstad: Karlstad University Studies.

Hallencreutz, D. (2002). Populärmusik, kluster och industriell konkurrenskraft: En ekonomisk-geografisk studie av svensk musikindustri. Uppsala: Kulturgeografiska institutionen, Uppsala Universitet.

Helmfrid, S. (1962). Östergötland" Västanstång": Studien über die ältere Agrarlandschaft und ihre Genese. Geografiska Annaler, 44(1-2).

Helmfrid, S. (1999). A hundred years of geography in Sweden. In S. Christiansen, P. Hagget, \& P, Vartiainen (Eds.). Swedish Research in Human Geography (pp. 19-54). Uppsala:

Swedish Council for Research in the Humanities and Social Sciences.

Hägerstrand, T. \& Buttimer, A. (1988). Geographers of Norden: reflections on career experiences. Lund: Lund University Press.

Jackson, D. (2013). Completing a PhD by publication: a review of Australian policy and implications for practice. Higher Education Research and Development, 32(3), 355-368. 
Johnsson, B. (1965). Åkerns omfattning vid 1600-talets mitt enligt de geometriska jordeböckerna: kulturgeografiska metodstudier tillämpade på Västmanlands län. Stockholm: Stockholms Universitet.

Johnston, R. \& Sidaway, J. D. (2015). Geography and Geographers: Anglo-American Human Geography Since 1945. London: Routledge.

Kabeer, N. (1999). Resources, agency, achievements: Reflections on the measurement of women's empowerment. Development and Change, 30(3), 435-464.

Kaplan, D. H. \& Mapes, J. E. (2015). Panoptic geographies: an examination of all U.S. geographic dissertations. Geographical Review, 105(1), 20-40.

Kaplan, D. H. \& Mapes, J. E. (2016). Where Are the Women? Accounting for Discrepancies in Female Doctorates in U.S. Geography. The Professional Geographer, 68(3), 427-435.

Kristoffersson, A. (1924). Landskapsbildens förändringar i norra och östra delen av Färs härad under de senaste tvåhundra åren: en kulturgeografisk studie. Lund: Lunds Universitet.

Larsen, P. O. \& Von Ins, M. (2010). The rate of growth in scientific publication and the decline in coverage provided by Science Citation Index. Scientometrics, 84(3), 575-603.

Lee, A. (2010). When the article is the dissertation: Pedagogies for a $\mathrm{PhD}$ by publication. In Aitchison, C., Kamler, B. \& Lee, A. (Eds.) Publishing pedagogies for the doctorate and beyond (pp. 137-155). London: Routledge.

Lobell, H. (2012). Monograph or Collection of Articles with a Summary? Why?. Forskarhandledning - introduktion, Avdelning för högskolepedagogisk utveckling, Lund: Lunds universitet.

Lundmark, M. \& Malmberg, A. (1988). Industrilokalisering $i$ Sverige: regional och strukturell förändring (No. 19). Department of Social and Economic Geography. Uppsala: Uppsala Universitet. 
Lönborg, S. (1897). Adam af Bremen och hans skildring af Nordeuropas länder och folk.

Uppsala: Uppsala Universitet.

Martin, G. J. (2015). American Geography and Geographers: Toward Geographical Science. New York: Oxford University Press.

Massey, D. (1994). Space, place and gender. Place: John Wiley \& Sons.

McDowell, L. (1992). Doing gender: feminism, feminists and research methods in human geography. Transactions of the Institute of British Geographers, 17(4), 399-416.

Paré, A. (2010). Slow the presses: Concerns about premature publication. In Aitchison, C., Kamler, B. \& Lee, A. (Eds.) Publishing pedagogies for the doctorate and beyond (pp. 30-46). London: Routledge.

Pratt, M. L. (1991). Arts of the contact zone. Profession, 33-40.

Peck, J. (2005). Struggling with the Creative Class. International Journal of Urban and Regional Research, 29(4), 740-770.

Pretorius, M. (2017). Paper-based theses as the silver bullet for increased research outputs: first hear my story as a supervisor. Higher Education Research \& Development, 36(4), 823837.

Schwerin, H.H.V. (1884). Herodots framställning af Europas geografi. Lund: Lunds Universitet.

Sharmini, S., Spronken-Smith, R., Golding, C. \& Harland, T. (2015). Assessing the doctoral thesis when it includes published work. Assessment and Evaluation in Higher education, 40(1), 89-102.

SFS 1993:100 (1993). Swedish Higher Education Ordinance [Högskoleförordningen]. Stockholm: Utbildningsdepartementet. 
SOU 2011:1 (2011). Svart på vitt - om jämställdhet i akademin. Betänkande av Delegationen för jämställdhet i högskolan. Stockholm: Fritzes.

Swedish Higher Education Authority [Universitetskanslersämbetet] (2016). Databas:

Doktorander och examina i högskoleutbildning på forskarnivå. http://www.scb.se/hittastatistik/statistik-efter-amne/utbildning-och-forskning/hogskolevasende/doktorander-ochexamina-i-hogskoleutbildning-pa-forskarniva/\#c_li_75815

Swedish National Agency for Higher Education [Högskoleverket] (2006). Utvärdering av grund- och forskarutbildning i kulturgeografi och grundutbildning i geografi vid svenska universitet och högskolor. Högskoleverket Rapport 2006:16 R: Stockholm: Högskoleverket.

Swedish Research Council [Vetenskapsrådet] (2006). forskarutbildningen i Sverige: Variation i volym, effektivitet och kostnader sedan tidigt 1990-tal. Stockholm: Vetenskapsrådet.

Thomson, I. (2001). Heidegger on ontological education, or: How we become what we are. Inquiry, 44(3), 243-268.

United Nations (2015). Human Development Report 2015: Work for Human Development. New York: United Nations Development Programme.

Järngren, A. \& Ventura, F. (1977). Tre samhällens förändringshistoria: exploateringen av den fysiska miljön $i$ historisk belysning. Statens råd för byggnadsforskning.

Wenger, E. (1998). Communities of practice: Learning, meaning, and identity. Cambridge: Cambridge University Press.

World Economic Forum (2015). The Global Gender Gap Report 2015. Geneva: World Economic Forum. 


1
2
3
4
5
6
7
8
9
10
11
12
13
14
15
16
17
18
19
20
21
22
23
24
25
26
27
28
29
30
31
32
33
34
35
36
37
38
39
40
41
42
43
44
45
46
47
48
49
50
51
52
53
54
55
56
57
58
60

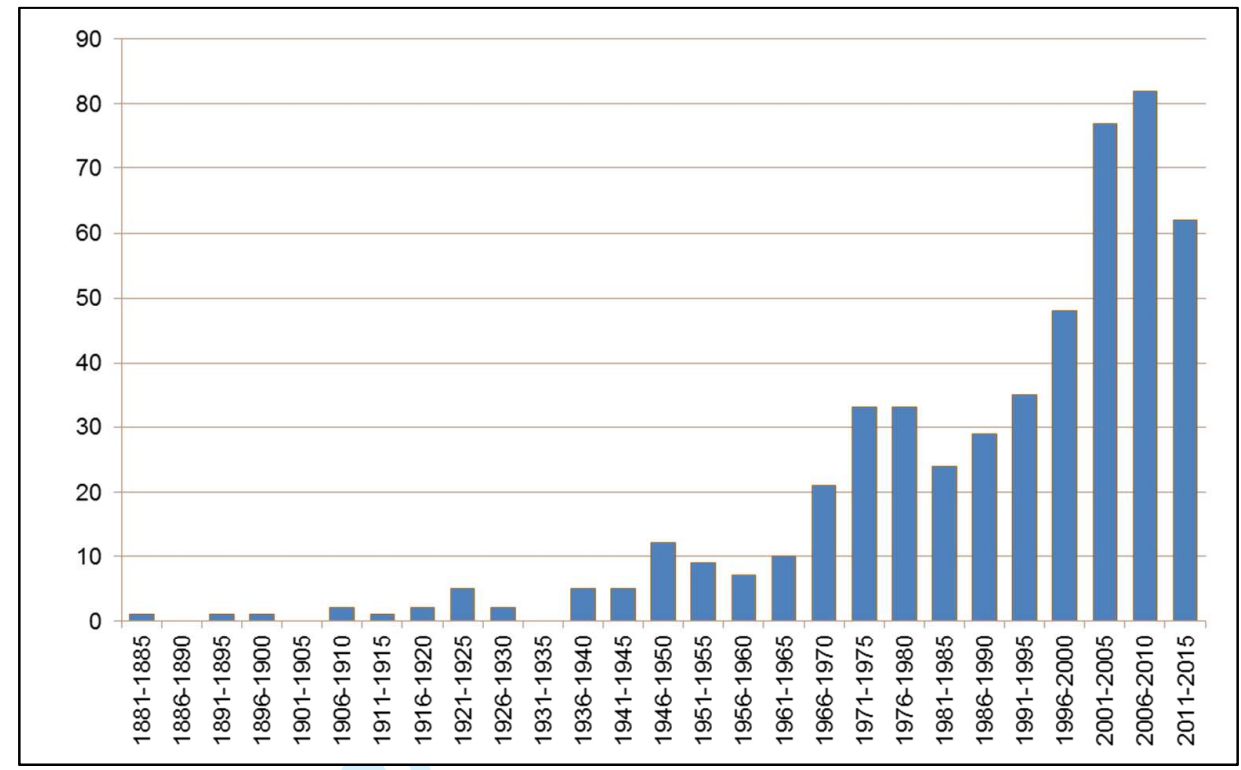

Figure 1. Number of doctoral dissertations in human geography, 1884-2015, N=507. 


1
2
3
4
5
6
7
8
9
10
11
12
13
14
15
16
17
18
19
20
21
22
23
24
25
26
27
28
29
30
31
32
33
34
35
36
37
38
39
40
41
42
43
44
45
46
47
48
49
50
51
52
53
54
55
56
57
59
60

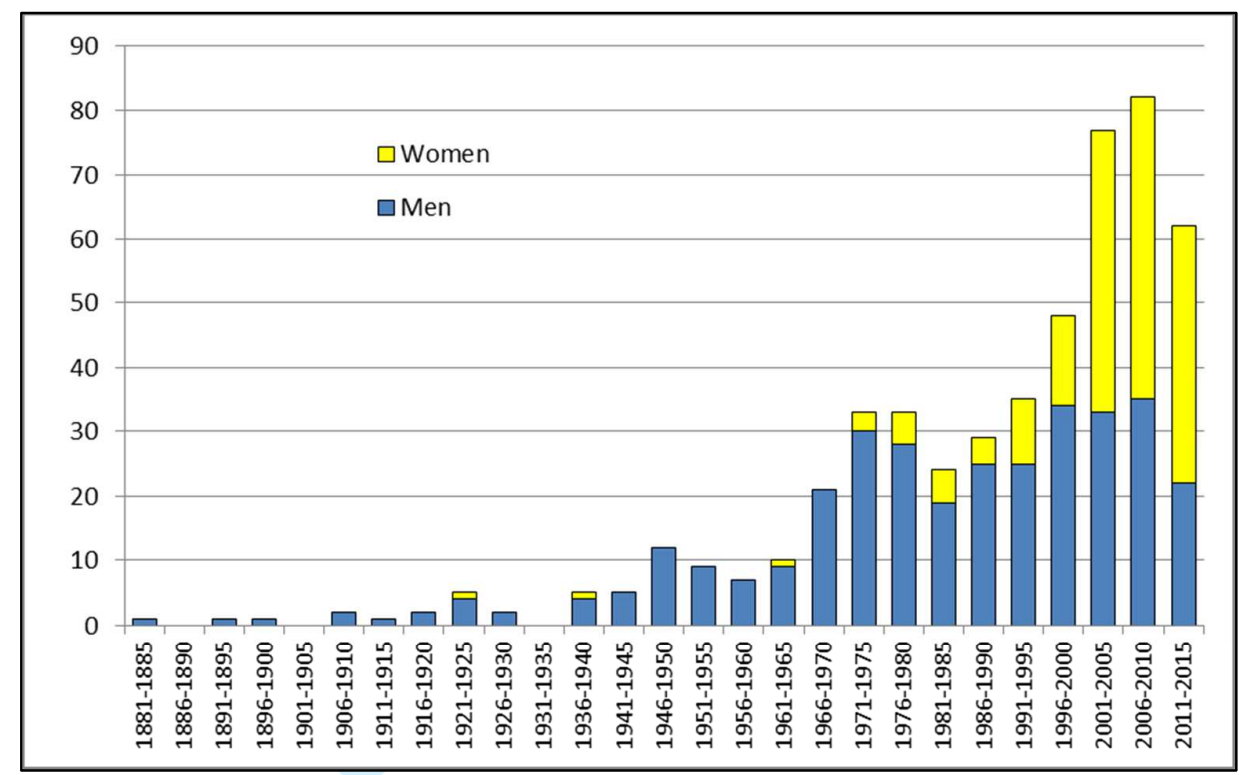

Figure 2. Number of male and female authors of dissertations in human geography, 1884-2015. 


1
2
3
4
5
6
7
8
9
10
11
12
13
14
15
16
17
18
19
20
21
22
23
24
25
26
27
28
29
30
31
32
33
34
35
36
37
38
39
40
41
42
43
44
45
46
47
48
49
50
51
52
53
54
55
56
57
58
60

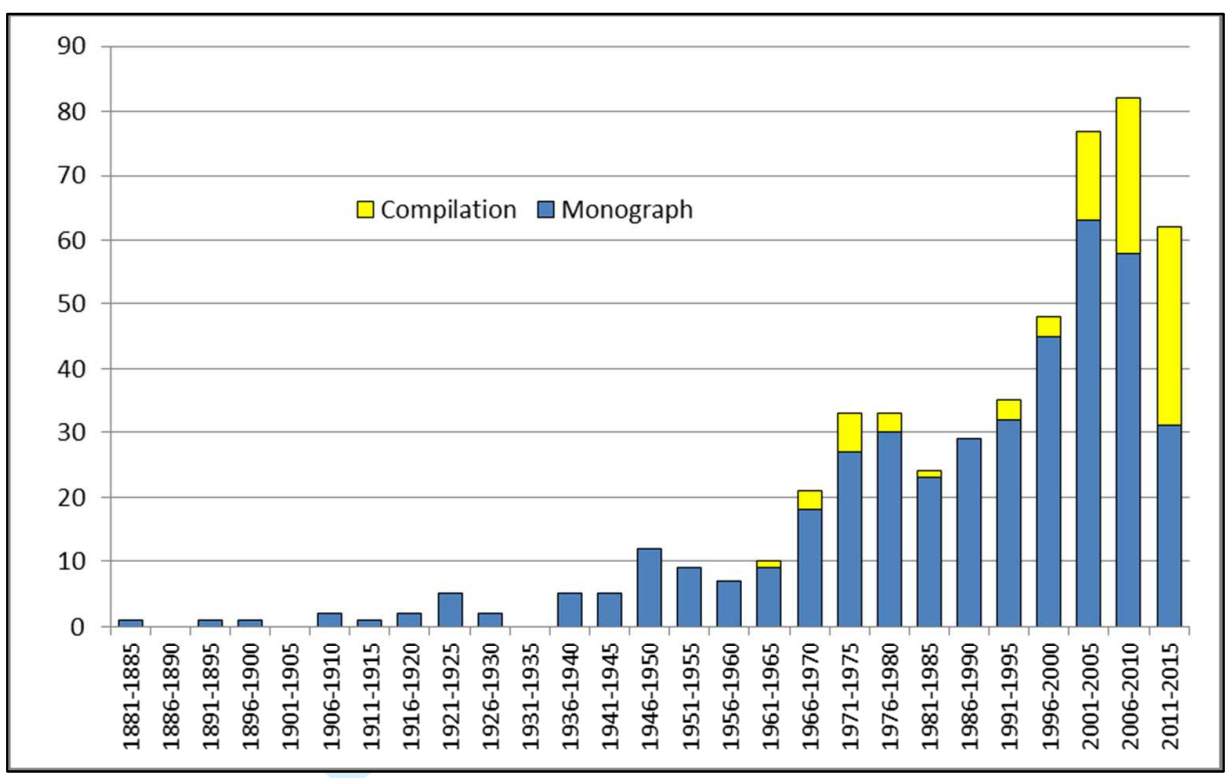

Figure 3. Number of monographs and compilation dissertations in human geography, 1884-2015. 
Table 1. Logistic regression of dissertation format (monograph versus compilation), odds ratios.

\begin{tabular}{llll}
\hline Ref: monograph & Model 1 & Model 2 & Model 3 \\
\hline $\begin{array}{l}\text { Sex (ref=male) } \\
\text { Female }\end{array}$ & 1.010 & 0.991 & 1.143 \\
$\log ^{10}$ Age & & $0.897^{* * *}$ & $0.893^{* * *}$ \\
University (ref=Uppsala) & & & \\
$\quad$ Lund & & 0.696 \\
$\quad$ Stockholm & & & 0.774 \\
$\quad$ Umeå & $-1.163^{* * *}$ & $2.779^{* *}$ & $2.951^{* *}$ \\
Constant (B) & 336 & 336 & $2.745^{* *}$ \\
$N \quad 0.000$ & 0.063 & 336 \\
Cox \& Snell R Square & 0.000 & 0.094 & 0.105 \\
Nagelkerke R Square & 386.842 & 347.022 & 0.158 \\
-2 Log likelihood & & 331.584 \\
\hline
\end{tabular}


Table 2. Number of articles, co-authorship and points in compilation dissertations across university institutions.

\begin{tabular}{|c|c|c|c|c|c|c|c|}
\hline & $N$ & Mean & $S D$ & $M D$ & Min & $\operatorname{Max}$ & Sig. \\
\hline \multicolumn{8}{|l|}{ Number of articles } \\
\hline Lund & 17 & 4.71 & 0.92 & 5 & 3 & 6 & \multirow{5}{*}{0.098} \\
\hline Stockholm & 15 & 3.73 & 1.28 & 4 & 2 & 6 & \\
\hline Umeå & 24 & 4.00 & 0.78 & 4 & 3 & 6 & \\
\hline Uppsala & 27 & 4.15 & 1.41 & 4 & 2 & 8 & \\
\hline Total & 83 & 4.14 & 1.16 & 4 & 2 & 8 & \\
\hline \multicolumn{8}{|l|}{ Number of co-authored articles } \\
\hline Lund & 17 & 2.24 & 1.48 & 2 & 0 & 5 & \multirow{5}{*}{0.001} \\
\hline Stockholm & 15 & 0.73 & 0.80 & 1 & 0 & 2 & \\
\hline Umeå & 24 & 2.04 & 1.12 & 4 & 0 & 5 & \\
\hline Uppsala & 27 & 1.07 & 1.57 & 1 & 0 & 6 & \\
\hline Total & 83 & 1.53 & 1.43 & 1 & 0 & 6 & \\
\hline \multicolumn{8}{|l|}{ Points $^{*}$} \\
\hline Lund & 17 & 3.01 & 0.66 & 3.16 & 1.66 & 4.00 & \multirow{5}{*}{0.033} \\
\hline Stockholm & 15 & 3.22 & 1.01 & 3.25 & 2.00 & 5.00 & \\
\hline Umeå & 24 & 2.74 & 0.76 & 2.88 & 1.16 & 4.16 & \\
\hline Uppsala & 27 & 3.55 & 1.24 & 3.16 & 2.00 & 8.00 & \\
\hline Total & 83 & 3.15 & 1.01 & 3.00 & 1.16 & 8.00 & \\
\hline
\end{tabular}


Table 3. OLS regression of points in compilation dissertations.

\begin{tabular}{llll}
\hline & Model 1 & Model 2 & Model 3 \\
\hline $\begin{array}{l}\text { Sex (ref=male) } \\
\text { Female }\end{array}$ & $0.415^{*}$ & $0.413^{*}$ & 0.268 \\
$\log ^{10}$ Age & & -1.718 & -1.652 \\
University (ref=Uppsala) & & & \\
$\quad$ Lund & & & -0.412 \\
$\quad$ Stockholm & & $5.467^{*}$ & -0.163 \\
$\quad$ Umeå & $2.829^{* * *}$ & 79 & $-0.544^{*}$ \\
Constant (B) & 79 & 0.069 & $2.745^{*}$ \\
$N \quad 0.056$ & 0.045 & 79 \\
R Square & 0.043 & & 0.132 \\
Adjusted R Square & & & 0.072 \\
\hline
\end{tabular}




\section{DOCTORAL DISSERTATIONS IN HUMAN GEOGRAPHY FROM}

SWEDISH UNIVERSITIES 1884-2015: AN ANALYSIS OF AUTHOR DEMOGRAPHICS,-DISSERTATION FORMATS AND PRODUCTIVITY

\section{INTRODUCTION}

The development of human geography as a discipline is usually told with reference to its most prominent scholars and ideas (see e.g. Johnston \& Sidaway, 2015; Martin, 2015). While there is no doubt of the great value of such accounts, such overviews can only convey glimpses of the research carried out in the discipline. This paper seeks to begin describingcontribute to the understanding of the development of the discipline from a different angle, that of doctoral dissertations. For most scholars, the doctoral dissertation is a career-defining piece of work, often the most important individual piece of research carried out and completed. As such it plays an important role not only for the individual scholar but more generally for knowledge production. It is, moreover, a key component of postgraduate education. In most countries, however, overviews of dissertations are not available (but see Kaplan \& Mapes, 2015, for a recent exception from the United States). This obstructs fruitful discussion on the development of the discipline.

The aim of this paper is to provide an exploratory overview of all doctoral dissertations in human geography published in Sweden. In addition to surveying the general trend over time for universities conferring doctoral degrees $1884-2015$, we pay specific attention to, first, the basic demographic characteristics of the authors (sexgender and age), and second, different formats of dissertations (monograph versus compilation). Third, for recent dissertations, we also explore author productivity by investigatingthrough using a points system which 


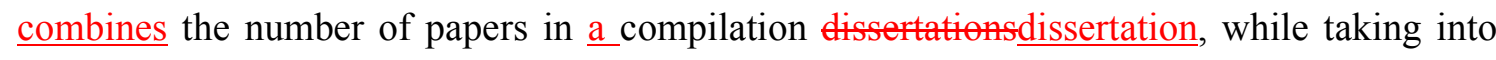
account co-authorship.

Our first focus, on demographics, aims to contribute to discussions about gender-bias in the discipline. While it is well known that human geography has a history of gender bias (see McDowell, 1992; Massey, 1994), a recent study from the United States (Kaplan \& Mapes, 2016) showed that the share of women completing doctorates in geography has increased dramatically during the last few decades. Buring the 1950 s to the 1970 s only about 5 to 10 percent of the doctorates in geography were written by women, but by 2012, this share had increased to 45 percent (Kaplan \& Mapes, 2016). The extent to which this trend can be found in other countries is currently unclear. Sweden is arguably of particular interest since it is widely held to be one of the most gender-equal countries (see e.g. United Nations, 2015; World Eenomic Form, 2015) and poliemakers havely prom in miversities (2016) highlight two main types of research into gender bias within the wider discipline of human-geography in the US: the first uses biographical and life history data to understand the lived experiences of women who were pioneers within the discipline; the second uses secondary data alongside some forms of qualitative enquiry to examine levels of exclusion and associated reasons. Our contribution here which relies on quantitative analysis reflects the second of these two approaches and is a first step towards subsequent qualitative enquiry which will investigate explanations for the patterns reported here. A further component of our interest in demographics is the author's age at the time of publication. Reforms of postgraduate education have long aimed at reducing the time it takes for postgraduates to receive their doctorates (see e.g. Swedish Research Council, 2006). Such reforms have been striving to transform doctorates into a "driver's 
license" for research rather than a life's work (Gren, 2005). As far as we know, there are no international studies on the age of $\mathrm{PhDs}$ in the discipline.

Our second focus, which seeks to survey the most basic characteristics of dissertations, is due to broad interest in changes in dissertation format. Recent decades have seen the emergence of a new form of doctoral dissertation in many Scandinavian universities and elsewhere. The traditional route through which a doctoral student joined an academic epistemic and discursive community was through demonstrating an addition to knowledge in the form of a monograph, a single tome consisting of around $60,000-80,000$ words where an overarching research question was examined in an exhaustive and comprehensive manner. This traditional route to joining the academy remains more or less sacrosanct in most countries (Lee, 2010). But since the 1960s in Sweden, the PhD monograph has been challenged by a new dissertation format: the compilation dissertation (sometimes referred to as “_PhD by publication").publication'). Here, a number of discrete articles in various stages of formation and publication are bound together with common themes, red threads and major contributions explained in an overarching summary (this summary is referred to as kappa in Swedish, i.e. cloak). We believe this is the first study to explore trends in dissertation formats for an entire country. We conduct a logistic regression on dissertations since 1964 to assess if the likelihood of completing this format varies systematically with demographic or institutional factors.

Our third focus, on author productivity, focuses solely on compilation dissertations. The recent emergence of compilation dissertations appears to be debated at most institutions, wherewith questions have been-raised concerningregarding how many papers should be included, to what extent co-authorship should be allowed, how to measure the quality of 
journals and whether the papers have to be published or submitted for publication. These questions not only have implications for maintaining similar quality standards across institutions, but also for the careers of postgraduate students and supervisors (Jackson, 2013; Pretorius, 2017). Surprisingly, there are no formal minimum requirements for a compilation dissertation apart from the general guidelines we report in Section 2. We believe this is the first paper to investigate author productivity empirically. We use a simple proxy for the productivity of $\mathrm{PhD}$ students completing this form of dissertation by assigning points, 1 point for each paper, divided by the number of authors, for all the papers in the dissertation. UsingWe fully recognize this is a blunt proxy: it does not take into account first authorship nor the relative contributions of authors. Nevertheless, by using this proxy as a dependent variable, we assessare able to make modest claims about the extent to which demographic and institutional variables show a significant relationship with author productivity within the discipline.

The remainder of the article is structured as follows. The next section (2) provides a eontextualization by discussingdiscusses postgraduate education in Sweden and recent international debates focusing on compilation dissertations. The data collected and associated methods are discussed in Section 3. The results/discussion section (4) presents both descriptive statistics-and ${ }_{2}$-modelling outcomes and a full discussion of the article ends with a discussion (Section 5) and conclusion (implications of the findings. Section 6). concludes.

\section{RESEARCH CONTEXT}

The history of Swedish human geography has been portrayed in a number of studies (see e.g. Hägerstrand \& Buttimer, 1988; Helmfrid, 1999; Buttimer \& Mels, 2006). As Asheim (1987) notes, at least since the definitive break with descriptive, regional geography in the 1950s, and 
the location of departments within social science faculties, Swedish human geography has had a high profile internationally. However, there is surprisingly little research carried out that explicitly focusses on postgraduate education and doctoral dissertations in the discipline. The work of Gren (2005) is an exception that discusses the recent transformation of postgraduate education within human geography. Doctoral education is both a product of, and a contribution to, the production and reproduction of “the university's core practices: research, education and outreach/engagement" (Elmgren et al., 2016:87). At its core, this highest form of education builds on the Western learning ideal of Platonic paideia; an ideal that honours both practical and subject-based learning and a form of socialization of individuals in relation to the surrounding society (Thomson, 2001). To provide the reader with a background to contemporary postgraduate education and doctoral dissertations in Sweden, it is important to explain that throughout most of the discipline's history the path to the doctorate was considerably less structured than it is today. It used to be relatively easy for those inclined to be enrolled as doctoral students to attend seminars and obtain at least some supervision from senior scholars. However, little financial support was provided and faculty funding was usually reserved for those that were close to the degree. This meant it generally took a lot of time to complete a doctorate. It also appears to have been largely up to doctoral students to figure out what was required of them (Gren, 2005). Clearly, reforms were needed to transform doctoral education.

$\underline{\text { The extent to which this relatively unstructured approach to doctoral education in Swedish }}$ human geography had a strong gender dimension is not clearly delineated in the literature. $\underline{\text { Kaplan \& Mapes (2016) show that during the 1950s-1970s in the US only about } 5 \text { to } 10}$ percent of the doctorates in geography were written by women, but by 2012 , this share had increased to 45 percent. Whilst observational evidence suggests a similar rise in Sweden at 
this time, thus far there is little empirical evidence to support this assertion. Sweden is arguably of particular interest since it is widely held to be one of the most gender-equal countries (see e.g. United Nations, 2015; World Economic Forum, 2015) and policymakers have actively promoted gender equality in universities (see e.g. SOU 2011:1).

Since the late 1990s Swedish postgraduate education in human geography has become much more structured and consists of four years of full-time study. To be accepted, students are required to hold a bachelor's degree in the disciple and often a master's degree. During these four years, students undertake temporary full-time employment at an internationally competitive level and may extend their studies for one additional year if they carry out teaching or perform administrative tasks in their department. Postgraduates spend about two thirds of their time working on their dissertations and about one third is devoted to courses (although this varies slightly across departments). Normally, a few courses are mandatory (typically in the philosophy of social science and on methodology) and are offered at departments, faculties or universities. There are also two to three annual national courses on various topics that are open to postgraduates from all human geography departments in Sweden.

Formally, the Swedish Higher Education Ordinance (SFS 1993:100) states that for a doctorate to be awarded the student must complete 240 educational credits, demonstrate broad knowledge of their chosen research field and recent, deep specialized knowledge on their chosen research questions. Moreover, a doctoral candidate must demonstrate the ability to critically review, assess and analyse new and complex phenomena independently through the choice of appropriate methods, make a contribution to knowledge and communicate this in 
national and international settings verbally and in writing. Further requirements are made in terms of contributing to responsible societal learning and ethics.

Considering these requirements, the growing popularity of a compilation dissertation appears to be related to the opportunities it offers postgraduate students to contribute more directly to international research and to obtain feedback from reviewers who are experts in their respective fields. As such, the review process complements, or possibly replaces, the seminars where doctoral students used to present and obtain feedback on the chapters of their coming monograph. It has also been argued that one of the main reasons behind the increasing popularity of compilation dissertations is a “"publish or perish"perish” culture within universities now (see Jackson, 2013; Pretorius, 2017) and the greater pressures academic staff are now subject to across Europe. Elmgren et al., (2016) argue that in the European policy context, the postgraduate education primarily serves the purpose of strengthening Europe's position in the global knowledge economy. The role of the universities is thus to produce the (creative) knowledge and human input to the contemporary "creative economy" (Peck, 2005).

Despite these trends and the associated lurch towards compilation dissertations, institutional guidelines and policies appear to be limited (Dowling et al., 2012; Jackson, 2013; Sharmini et al., 2015; Pretorius, 2017). In her review of Australian policy, Jackson (2013) found considerable variation across universities regarding the number and type of papers within a compilation dissertation and associated co-authorship guidelines. Whilst Jackson (2013) emphasizes that there are significant benefits in compilation dissertations, both for postgraduate students and supervisors, there appears to be insufficient guidance on the quantity and quality of publications as well as problems with how to evaluate such dissertations compared to the traditional monograph. Sharmini et al., (2015) also highlight 
how many examiners, although generally positive towards compilation dissertations, are concerned about the individual contribution of a doctoral candidate when co-authoring in terms of their individual intellectual contribution. It can be argued that the lack of a policy debate on what constitutes an adequate compilation dissertation is partly determined by a lack of data which limits the depth of discussion when comparing dissertation types and improving existing policies and legislation. We now turn to the unique dataset we utilize to try to contribute to the growing debate in a number of countries (Jackson, 2013; Sharmini et al., 2015).

\section{DATA AND METHODS}

\subsection{Compiling a database of dissertations}

Our first task was to compile a database, a task which proved more time-consuming than anticipated and included numerous approaches to identifying potential cases. First, most departments present the title of the most recent dissertations produced on their website or through a publication series. Second, library search engines and Internet sites (such as www.avhandlingar.se and www.libris.kb.se) also allowed the identification of dissertations. Third, a departmental survey carried out as part of a national evaluation of postgraduate studies by the Swedish National Agency for Higher Education (2006) provided the titles of all doctoral dissertations published 1970-2004. Fourth, prof. em. Gunnar Törnqvist kindly provided a literature list on doctoral dissertations from a reading course that was once held at Lund University. Fifth, a further source was Buttimer \& Mels (2006) who list dissertations in geography 1884-2000. By cross-examining these various sources it seems likely that all dissertations in the discipline produced in Sweden until 2015 have been identified, although it may be that one or two have gone undetected. 
After compiling a list of all dissertations, theses were borrowed from libraries or downloaded from the Internet. We then excluded dissertations in physical geography, but maintained earlier regional studies which included substantial human geography content. This task was made by subjective assessment of the content but we also made use of earlier classifications of dissertations by Helmfrid (1999) and Buttimer \& Mels (2006). Finally, we only included dissertations that had been published by institutions with the right to award doctoral degrees in Human/Economic Geography (or similar wording). In Sweden, seven universities (Gothenburg, Karlstad, Lund, Stockholm, Umeå, Uppsala and Örebro) have the right to award [examensrätt] such a doctoral degree. ${ }^{1}$ This overview is restricted to only those dissertations produced at these universities. ${ }^{2}$

One further issue was co-authorship as three dissertations had two authors (i.e. Ventura \& Järnegren_\& Ventura, 1977; Lundmark \& Malmberg, 1988; Blom-Mondlande \& Jansund, 2003). Since the formal rules for a co-authored doctoral dissertation are that each author's contribution should be identifiable, we count a co-authored dissertation as two dissertations. Hence, in the empirical analyses, each author is considered to be a sole author of a dissertation, so these three dissertations are counted as six. This is appropriate as many compilation dissertations are also co-authored (see below).

\subsection{Demographic characteristics of authors}

The gender of each author was identified through first and surnames. In a few cases we relied on contacts with colleagues at the authors' departments to correctly identify the gender. As

\footnotetext{
${ }^{1}$ Strictly speaking, Gothenburg has the right to award a doctoral degree in economic geography; Lund University in human geography/economic geography and Stockholm University in geography "with specialization in Human Geography". For further discussion about the relevant institutions see Helmfrid (1999).

${ }^{2}$ Doctoral dissertations produced at other universities (e.g. at KTH Royal Institute of Technology and at Linköping University) could have been included had those universities had the right to award a doctoral degree in human geography.
} 
regards the author's age, we were able to identify the year of birth for the vast majority of authors by means of the National Library of Sweden (this was not possible in only 30 cases, primarily for the oldest dissertations).

\subsection{Format of dissertations}

A somewhat unexpected problem turned out to be classifying a dissertation as a monograph or a compilation. We learned that in a few cases (e.g. Helmfrid, 1962; Claeson, 1964) the entire text of the dissertation had been published as a single journal article of more than 100 pages (which appears to have been a cost-saving strategy as postgraduate students used to be responsible for the costs of printing). We decided that such dissertations should be classified as monographs. Finally, we also found that the language varied in a few compilation dissertations (e.g. Hallencreutz, 2002) where some papers had been written in Swedish and others in English. In those cases, we decided that the language of the summary (kappa) should determine the classification.

\subsection{Author productivity}

Needless to say, author productivity is a difficult facet to quantify in a dataset. Our approach in this paper is to use a simple points-based system that is used informally at some university departments in Sweden. This aims to provide a crude measure of the independent productivity of authors of compilation dissertations. The informal system, referred to as the 3-points system, is that the score for each paper is 1 divided by the number of authors. In other words, a single-authored article by the $\mathrm{PhD}$ student is a 1 , an article with 2 authors is 0.5 , an article with 3 authors is 0.33 , and so on. These figures are then totalled for all the articles in the compilation dissertation. The guiding rule is that a total score of 3.0 (or higher) is an acceptable level to demonstrate independent productivity. Using this proxy, we assess the 
extent to which there are any significant differences in terms of author productivity across gender, age and university institution.

It should be emphasized that this is a blunt proxy since it does not take into account the quality of the papers, whether they are published in prestigious journals (or not published at all, although the general rule is that they should be of "publishable" quality), or whether they include empirically--_collected data. Moreover, it assumes that all authors contributed equally to the work (and that all who made substantial contributions are acknowledged as co-authors). It is not possible to analyze the ordering of authors as an indicator of relative contributions since it seems that alphabetical ordering is still quite common. Finally, it needs to be recalled that postgraduate students have to take courses in addition to writing their dissertation. We do not control for this when estimating the determinants of author productivity (since there are only minor differences between the departments as regards the number of courses postgraduate students have to complete). Nor have we been able to control for the time it takes for postgraduate students to complete their doctoral degree.

\subsection{Methods of analysis}

The approach adopted in this paper is largely descriptive, focusing on providing a general overview of dissertations and their authors. However, we have also relied on multivariate analysis to explore the data further in two additional ways. First, to see the extent to which our demographic and institutional variables had any relationship with the format of a dissertation. Specifically, whether gender, age or institution influenced the likelihood of producing a compilation dissertation (instead of a monograph) via a logistic regression on a restricted sample of dissertations produced since 1964 (this was the year when the first compilation dissertation was produced). Out of the 448 dissertations produced since 1964 (359 
monographs and 89 compilations) we excluded dissertations from Gothenburg, Karlstad and Örebro in the regressions since they had too few compilation dissertations, leaving the final sample with 351 dissertations (268 monographs and 83 compilation dissertations). Dummy variables were created for the four institutions with a sufficient sample size: Lund, Stockholm, Umeå and Uppsala.

Second, we conducted an OLS regression to assess the extent to which the demographic and institutional variables had a relationship with author productivity, proxied by using the points system as explained above. The sample here was the 83 compilation dissertations. We transformed two variables (age and points were logged by 10) so that skewness and kurtosis were within safe limits. We also used dummies for key departments. We now turn to the results starting with the descriptive statistics.

\section{RESULTS AND DISCUSSION \\ 4.1 General overview}

Figure 1 below shows the number of doctoral dissertations: 507 dissertations from 1884 to 2015. According to our investigation, the first doctoral dissertation to be published in the discipline at a Swedish university was written by Schwerin (1884) at Lund University. Evidently, in the early years progress was notably slow and it then took more than a decade before the next dissertations were published (by Ahlenius in 1895 and Lönborg in 1897, both at Uppsala University). In fact, 50 years after the first dissertation, only 14 more dissertations had been published (6 at Lund University, 6 at Uppsala University and 2 at Stockholm University). However, from 1936 and onwards, dissertations came out almost yearly and a notable increase occurred during the late 1960s. The 1960s and 1970s arguably represent a highpoint for the discipline, with significant societal impact during the construction of the 
welfare state. The number of dissertations has continued to be published in ever greater numbers (though not quite in a linear fashion). Between 2006 and 2010, a record number of 82 dissertations were produced.

\section{--- FIGURE 1 ABOUT HERE ---}

This rapid increase during the last few decades raises the question of whether this trend is unique to human geography or whether it simply reflects a general increase of doctoral dissertations in the social sciences. The Swedish Higher Education Authority (2016) publishes statistics on the total number of doctoral degrees awarded in the social sciences (by university) going back to 1973 , which allows for a general comparison of the trend. Such a comparison shows that the share of dissertations in human geography account for 3.9 percent of the total social sciences during 1973 to 2014. The high- and low-points of 1977 (13.9 percent) and 1978 (1.0 percent) stand out as extreme values. Apart from those exceptions the general trend is clear and points to a diminishing share of dissertations in human geography compared with the rest of the social sciences. A linear trend line (not shown) starts at 6.0 percent in 1973 and ends at 2.6 percent in 2014. In terms of shares, then, this clearly suggests that the discipline is losing ground in comparison to other social science disciplines.

Our database also allows us to investigate the institutions where the dissertations were produced. Unsurprisingly, it turns out that the two oldest universities have been the most productive with Uppsala first, where 24 percent $(n=121)$ of the dissertations were published, closely followed by Lund with 23 percent $(n=119)$ and then Stockholm with 21 percent $(n=107)$. Combined, these three institutions account for more than two-thirds of the human geography dissertations in Sweden. Gothenburg University, where the first dissertation was 
published in 1936, ranks fourth with 75 dissertations (15 percent) and Umeå University (which attained university status in 1965) have produced 55 dissertations (11 percent). The two youngest universities Karlstad (1999) and Örebro (1999) have produced 21 and 9 dissertations (4 and 2 percent) respectively. While these figures are perhaps unsurprising, looking at the recent trends is quite revealing. Among the four largest universities, Uppsala, Stockholm and Gothenburg have had a stable share of dissertations since the late 1960s, whilst Lund is experiencing a noticeable downward trend. The younger institutions of Umeå, Karlstad and Örebro are now publishing a larger share.

\subsection{Demographic characteristics of the authors}

An issue that has been given a lot of attention in academia in recent decades is the gender balance of faculty staff. As shown in Figure 2 below, a gender bias has existed in Swedish human geography during most of the discipline's history. In fact, during the first hundred years only 15 women published a doctoral dissertation, comprising a meagre 9 percent of the total. It took almost 80 years after the first woman, Anna Kristoffersson (1924), defended her dissertation in Lund before a noticeable change occurred during the 1990s. Whilst progress was slow in the first seventy years of the last century, it has been very dramatic since then.

\section{--- FIGURE 2 ABOUT HERE ---}

Indeed, since 2000 a majority (59 percent) of dissertations have been published by women. Whilst women appear to have broken through the glass ceiling at the doctoral level, we have not examined the gender balance in taught postgraduate education course (it might very well be that women constitute the majority of these students). Overall, the high number of women 
successfully defending doctorates shows that discussions about gender balance in the discipline need to be nuanced. ${ }^{3}$

Turning to the age of authors, the trend was less distinct. While age appears to have increased quite steadily until 1956-1960, peaking at a mean age of 43, it then fell to 36 years in 19761980, increasing again to a mean age of 42 in 1991-1995, before falling again to about 36 years since 2001. Cross-tabulations of author age with other factors in the database only reveal that authors of compilation dissertations are almost four years younger on average than monograph authors. The general impression is of a rather stable age-profile in the discipline over time $($ Mean age $=37$, Min. $=26 ;$ Max. $=65 ; \mathrm{Md}=36 ;$ Std. dev. $=6,8)$.

\subsection{Format of dissertations}

As can be seen from Figure 3 below, the vast majority of doctoral dissertations have been published as monographs $(\mathrm{N}=418,82$ percent). While a handful of compilation dissertations were published from 1965 to 2000 (the first by Bruno Johnsson at Stockholm university in 1965), from 2001 the proportion of compilation dissertations has increased markedly with this dissertation format now being as popular as a traditional monograph (in total 89 compilation dissertations have been published, constituting 18 percent of all doctoral dissertations).

\section{--- FIGURE 3 ABOUT HERE ---}

The popularity of compilation dissertations varies across institutions. This format is a rare phenomenon in Gothenburg and Karlstad (only 3 have been published in the former

\footnotetext{
${ }^{3}$ We made an attempt to investigate the academic careers of the 82 individuals that published their dissertation during the 1990 s. Using the Internet and the authors' own knowledge, we were able to conclude that 27 percent of the men had made it to the rank of professor, but this share was even higher among females (36 percent). This again underscores the need to nuance the debate concerning gender balance in the discipline.
} 
institution, 1 in the latter), but elsewhere it appears to have become a popular alternative to the traditional monograph. This is particularly the case in Umeå where 24 compilation dissertations have been published corresponding to a total share of 44 percent of all doctoral dissertations. The largest number of compilation dissertations have been published in Uppsala $(\mathrm{N}=27$ corresponding to 22 percent of the total). The other two older universities Lund $(\mathrm{N}=17$, 14 percent $)$ and Stockholm $(\mathrm{N}=15,14$ percent $)$ have a similar share to each other.

Another major trend is evident: an increasing number of doctoral dissertations are published in English. Until the 1960s only a handful of dissertations were in English (only 2 percent of the total have been published in languages other than Swedish or English) and the vast majority chose to publish their dissertation in Swedish. During the 1960s this started to change and since the 1990s about half of all dissertations have been published in English, reaching 74 percent in 2011-2015. To a large extent this increase is related to the growth of compilation dissertations (92 percent of which are published in English).

\subsubsection{Multivariate analyses of dissertation format}

As explained in section 3.5, we use a simple logistic regression model to see if any relationships could be detected between demographic and institutional variables and the probability of completing a compilation dissertation. The results are shown in Table 1 below in which the likelihood of publishing a compilation dissertation (as opposed to a monograph) has been estimated.

--- TABLE 1 ABOUT HERE --- 
Model 1, with just gender in the model, is not significant and has no explanatory power over the choice of dissertation format. Model 2, with gender and age, is significant and explains 6$9 \%$ of the choice between a monograph and compilation dissertation with the odds of completing a compilation dissertation decreasing by 0.897 each unit of $\log ^{10}$ age. Model 3 is significant and as a whole explains $10-16 \%$ of the likelihood of completing a compilation dissertation. Holding other factors constant, the model shows two significant variables: age has similarlya negative influence on the probability of completing a compilation dissertation; going to Umeå increases the probability, by a factor of 2.951. An interaction term with age/gender did not add anything to the model. We now turn to assessment of the independent productivity of the authors using only the restricted sample of compilation dissertations.

\subsection{Author productivity}

The quality of papers included in compilation dissertations vary. Here, we have been forced to treat them all in the same way, only paying attention to the number of papers and the number of co-authors per paper. Table 2 below shows that there is quite a large difference across institutions in terms of the numbers of papers per dissertation, ranging from 2 to 8 with a median and mean figure of 4 . The exceptions are dissertations from Lund where the number of articles is higher (Mean 4.71) than other institutions (mean 4.14). Considerably more variance is found for the number of co-authored articles. Stockholm stands out with an average of 0.73 co-authored papers compared with Lund where the average is 2.24. Turning to the number of points, the lowest score of 1.16 and the highest score of 8.00 implies that author independence varies considerably. Among university institutions, Umeå stands out with the lowest average score. 
Putting these findings together, Table 2 below suggests that when using the points system as a proxy, the most "productive" "productive' dissertations have been from Uppsala, followed by Stockholm, Lund and finally Umeå (significant at the 95\% level). Interestingly, differences between institutions are not driven by the number of articles within a compilation dissertation (which is highest in Lund and lowest in Stockholm, significant at the $90 \%$ level) but by the degree of co-authorship of articles, presumably by supervisors, which is highest in Lund followed by Umeå (significant at the $99.9 \%$ level). This practice is least common in Stockholm. We can see that Lund's advantageproductivity in the number of articles is, in a sense, underminedtempered by the high number of articles which are co-authored.

\section{--- TABLE 2 ABOUT HERE ---}

\subsubsection{Multivariate analyses of author productivity}

We now turn to the multivariate model to isolate the influence of each factor in turn. To assess the factors that contribute to productivity as proxied by the points system, we conducted an OLS regression with the restricted sample of 83 units, the results from which are shown in Table 3. Including the number of articles and the number of co-authored articles as independent variables would mean the model transgressed two key requirements: no multicollinearity and the normal distribution of residuals. The model below displayed VIF figures for multicollinearity that are within safe limits and residuals are distributed normally.

\section{--- TABLE 3 ABOUT HERE ---}

Model 1, with just gender as an independent variable, shows how women candidates attain, on average, 0.42 more points than men (significant at the $95 \%$ level), with the model as a whole 
explaining $4 \%$ of the variance in points. Adding age in Model 2 changes little. When we add institutional dummies in Model 3, Umeå emerges as significant at the 95\% level with, ceteris paribus, attendance at this university reducing the point score by 0.5 . At the same time, we can see that the gender dummy loses significance. As Model 3 explains only $7 \%$ of the variance in the dependent variable, the OLS regression highlights overall how author productivity (as proxied by points) from a compilation dissertation is influenced by unobservables, such as skills, supervisory expertise, supervisory involvement, not most of the independent demographic or institutional variables in the model.

\section{DISCUSSION}

Whilst a number of conspicuous Two findings jump out immediately from the analysis above we will restrict the discussion to focus on: the significant recent increase in the number of compilation dissertations in the discipline and the better gender balance of completed doctorates in recent decades, whilst linking this to broader debates about reforms in the university sector in Seandinavia. We now discuss each in turn.

The rise andOur findings show that for a small discipline such as human geography, there is significant variation in the prevalence of compilation dissertations across universities and that younger $\mathrm{PhD}$ students are preferring this format (see Table 2). This warrants further discussion. The rise of compilation dissertations is perhaps not that surprising when one considers the incentives for $\mathrm{PhD}$ students, departments and faculties. For example, Fridlund (2010) suggests it may be easier to fail the degree when completing a monograph as compilation dissertations (almost) always contain some published work which has been vetted by reviewers and an editor. Including published prose in a compilation dissertation therefore decreases the likelihood that an examiner will take a very negative stance. $\mathrm{PhD}$ students are 
also concerned about their career prospects in the labour market. Securing a position within academia depends partly on demonstrated ability to publish and to secure research funds (and to a lesser extent on the ability to teach well). In this respect, the production of published articles within a compilation dissertation increases the speed with which a $\mathrm{PhD}$ candidate will be considered for a university job (Lobell, 2012).

There is also a temporal issue here which deserves consideration. It may well be that publishing during a $\mathrm{PhD}$ can increase short-term job prospects but this is not to say the strategy bodes well for long-term careers within academia. Paré (2010) highlights how rushing students into publishing may not yield long-term benefits as researchers who have completed a compilation dissertation may struggle to attain the necessary independence and self-reliance to advance quickly within an academic environment. Indeed, such researchers may become path dependent on the article format and lack the experience and confidence to tackle monographs and edited volumes during their careers.

Furthermore, Paré (2010) usefully highlights how supervisors also often have a significant interest in the production and completion of a compilation dissertation. As they often play the role of a silent second author of the dissertation, dependent on contextual norms, supervisors may remain invisible or, more commonly nowadays in the social sciences, co-author part of the dissertation in the form of journal articles. But whilst co-authorship may be beneficial for a supervisor in terms of status and possible promotion, there is a possibility it could hinder a doctoral candidate's own career if the student is unable to clearly explain their precise contribution to published articles. In some respects, supervisors who co-author articles with doctoral students are getting paid twice - once in terms of the in kind payment for the supervision process, and once in terms of status from fast publications. Overall, there is a 
considerable incentive here for supervisors to nudge students towards a compilation dissertation.

A broader point is that funding models within a faculty and university in Scandinavian countries at least partly rely on publication outputs. Those in leadership roles inwithin departments and universities therefore have an incentive to encourage $\mathrm{PhDs}$ to complete compilation theses as the publication of articles during and not after the duration of a PhD brings extra resources to the department'sinstitution's coffers. By highlighting Highlighting the incentives at play in the choice of dissertation format for $\mathrm{PhD}$ students, supervisors, institutes and faculties we aim to contribute to the debate about the opportunities and challenges of a compilation dissertation. It is important to keep in mind that there are also at number of advantages with the compilation format that may well increase the quality of research, e.g. doctoral students being able to rely on 'supervision' from reviewers and editors which would otherwise not be available. Even so, our findings show that there is significant variation across universities (see Table 2) and for a small discipline such as human geography, this variation warrants further discussion or else there is a risk that quality and skills are replaced by metries.is one element of the political economy of doctoral education: in other words, how actors and institutions in academia compete for and use resources and power in relation to doctoral students.

In addition to the points raised above, of particular relevance here is the issue of language: that the majority of international journals require manuscripts in English. Such a requirement offer a considerable advantage to 'native' English speakers, whether a supervisor or the doctoral candidate: the tacit knowledge and precision honed through socialization in an $\underline{\text { Anglophone environment allows an ease of expression easily detected by reviewers and }}$ 
editors. The barriers to entering the publishing 'community of practice' (Wenger, 1998) are $\underline{\text { therefore considerably higher for 'teams' without a 'native' speaker on board. As Canagarajah }}$ (2007) highlights, proficiency for these 'teams' is based on learning by doing and adaptation to the (often mixed) signals and message received from editors and reviewers. The choice of a compilation dissertation, often by younger candidates, brings doctoral candidates into $\underline{\text { linguistic 'contact zones' (Pratt, 1991) much sooner. Exclusion from these zones and }}$ 'communities of practice' for non-native speakers is exacerbated for scholars who, as Canagarajah (2002) highlights, need to learn to use discursive strategies to package articles in $\underline{\text { the necessary format for acceptance and publication (even if this detracts from the scientific }}$ rigour of the manuscript).

It is important to highlight at this stage that more than 70 percent of all dissertations are now published in English. While this trend clearly helps the internationalization of Swedish postgraduate students, little is known about whether this helps or possibly damages their careers. Moreover, whilst the incentives at different scales support the choice of a compilation thesis in Sweden when the linguistic barriers of diction and tone are overcome (which, we believe, also holds across Scandinavia more broadly), this choice may lead to a tension with the broader aims of the academy (in addition to teaching and pure research): to inform debate in the society (which largely finances the academy) through engaging in public discussions based on applied research. The hegemonic position of English as the lingua franca of academia alienates universities and their scholars (in the non-Anglophone world) from the citizens they are supposed to be supporting most directly. Swedish human geography has had a tradition of maintaining strong links with society. OurIn a period of considerable societal change, the extent to which human geography can now contribute fully to current national and 
$\underline{\text { Scandinavian policy debates on urban planning, social cohesion, economic growth and }}$ $\underline{\text { inequality using the international lingua franca are currently unclear. }}$

$\underline{\text { In addition, academia can often be depicted as aloof and distant: an elitist gown is often }}$ $\underline{\text { resented by people in town. Publishing in a foreign (albeit global) language, English, can only }}$ reinforce the separation from mainstream society. In this respect, there appears to be a contradiction between the incentives at the individual and institutional levels and the relationship the academy has (in the non-Anglophone world) with it's citizens. One $\underline{\text { consequence of this may well be a reversion amongst citizens (both close to universities and }}$ further afield) to what Bauman and Briggs (2000) refer to as the 'Herderian Triad' where $\underline{\text { language, community and place are seen as inseparable and insoluble. Here, English, the }}$ language of globalization and the movers who have explored the world as trade barriers and borders have dissolved in the past three decades, is seen not as a cosmopolitan medium to attain greater understanding of people and phenomenon but as a threat: it is the language of global elites and unwelcome immigrants (not just foreign students but economic migrants and refugees to boot).

This is not to say that the dominance of English-language journals is the only or even main influence on the apparent greater gulf between universities and society.

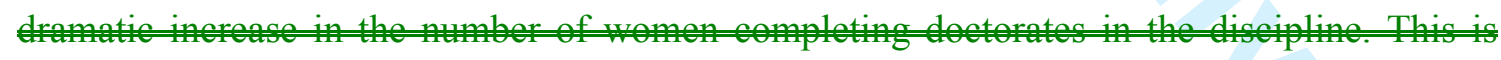
surprising for forst, the extreme gender inequality before the millennium. Second, university policies (such as for recruitment) still emphasize the need for a better gender balance, which gives rise to the question of whether the fact that women now constitute a majority of completed doctoral dissertations has gone completely unnoticed. It is possible that within senior ranks (lecturers and professors) a more equal gender balance may 
be attained shortly, now that there is a balanced cadre of candidates to choose among. A key question is how the topics investigated in human geography have changed since the recent rise of women doctoral candidates.

The promotion of competition and use of the market mechanism within and between Scandinavian universities has had a significant impact on the relationships between universities, researchers/teachers, students and surrounding society. Such reforms within the university sector have contributed to a highly-specialized subdivision of knowledge, greater differentiation and specialization (as reflected in the number of newly-established scientific journals, Larsen and Von Ins, 2010) as well as an increasingly obsessive focus on outputs: patents, publications, prizes, citations, funding, finished students. Academics, departments and faculties are increasingly assessed in relation to these output measures. The extent to which this has impacted negatively on the tuition and training process for doctoral students is a pertinent question (Björkman, 2015): as well as the ability of university staff to engage $\underline{\text { deeply in debates in society at large. }}$

Our second key finding is the dramatic increase in the number of women completing doctorates in the discipline. This is surprising for at least two reasons. First, the extreme gender inequality in the discipline before the millennium. Second, university policies (such as for recruitment for doctoral candidates) still emphasize the need for a better gender balance, which gives rise to the question of whether the fact that women now constitute a majority of completed doctoral dissertations has percolated through to university policy or not. One would expect that an equal gender balance within senior ranks (lecturers and professors) is close now there is a balanced cadre of candidates to choose among. One approach to $\underline{\text { theorising the better gender balance within doctoral candidates is to apply Kabeer's (1999) }}$ 
conceptualization of empowerment (which, inter alia, is influenced by Amartya Sen's $\underline{\text { entitlement approach) to this case. }}$

Kabeer (1999) argues that gender empowerment can be understood as the ability to exercise $\underline{\text { strategic and transformatory choices (within the constraints of a contextual choice set) based }}$ on access to and control over resources (defined broadly as current and expected assets and entitlements) and agency (the ability to define goals and pursue them despite countervailing opposition) leading to achievements (outcomes). Kabeer (1999) stresses the importance of the $\underline{\text { contextual choice set from which individuals are or are not able to make and act upon choices }}$ (and refers to Bourdieu's, 1977, notion of doxa): that this choice set is predicated on existing (often unconscious and naturalised) norms and values within a society.

Applying this framework to the better gender balance within doctoral students in human geography appears fruitful. Within a context of active policies to promote gender equality within one of the most gender-equal countries in the world, since the millennium women in Sweden have successfully utilized their seemingly better academic grades at undergraduate and postgraduate levels and the networks fostered during their studies to enter and, importantly, complete doctoral studies in human geography. But the choice to apply for doctoral positions in the discipline (which, in part, is still imbued with the remnants of previous patriarchal approaches) is only the first step: selection onto a shortlist; being offered a doctoral post; navigating the mandatory educational requirements of the programme (and often some teaching/administration responsibilities); working with a supervisor or supervision team; producing drafts, chapters/articles; and successfully defending the dissertation are all part and parcel of a doctoral process. During this endurance test (for that is what doctoral studies often are), agency and doxa are intertwined: the ability to pursue the goal of a 
doctorate is conditioned by the value-laden choice set candidates face: prominent examples of flourishing academics who are women within similar departments, faculties and universities (as well as in broader society) may well have played as important a role as written policy statements and intentions. The implication of this may be that the rapid rise of women as successful doctoral candidates within the discipline in Sweden may be hard to replicate in countries, especially in the global South, where gender equality is less advanced and the doxa is undoubtedly different.

\section{CONCLUSIONS}

This paper has provided an overview of all doctoral dissertations in Swedish human geography between 1884-2015. The specific focus has been on describing the demographics of the authors (looking in particular at age and gender), the format of dissertations (monographs versus compilation dissertations) and on exploring productivity variations for authors of compilation dissertations. The overall results show that the number of doctoral dissertations in human geography has increased substantially during the last half century. In fact, almost 44 percent of all dissertations have been published since the turn of the millennium, which suggests that human geography in Sweden is thriving like never before. However, other social sciences have also increased their doctoral dissertation publication rates. In fact, human geography only accounted for 3.9 percent of dissertations published in the social sciences during the last four decades and However, the discipline is contributing a decreasing share of doctoral dissertations since the 1970s. In that light, the future of the discipline may not be as bright as at first glance.

In terms of demographics, we find evidence of both stability and change. First, the age of the authors remains relatively stable, despite reforms of postgraduate education aiming at 
reducing the time it takes for postgraduates to receive their doctorates. Learning evidently takes time in the Swedish system and the average age of receiving a doctorate in the discipline is 37 years $(\mathrm{Md}=36)$.. Second, doctoral candidates have changed over time from being almost exclusively men to now having a better gender balance. Since 2000 a majority (59 percent) of dissertations have been published by women, which points to the need for a nuanced discussion about gender in the discipline.

Another notable trend is writing a compilation dissertation instead of a monograph, with the latter format nowadays accounting for less than half of all dissertations. This is quite a significant change and a departure from the traditional view of a doctoral thesis. Results show that being young university increases the likelihood of completing a compilation dissertation. Ongoing discussions in many institutions are a clear sign that the lurch towards compilation theses needs to be openly discussed in order to improve postgraduate education and the discipline.

The results further show that for those who publish their dissertation as a compilation, there is significant variation in terms of author productivity, measured by the number of singleauthored and co-authored papers included in the dissertation. Our statistical analysis shows that individual author productivity is, for some reason, lower if attending Umeå University, and that age, gender and attending any of the other institutions (which have a reasonable number of compilation theses) does not have a significant impact on productivity. Our interpretation is that individual author productivity (at least when proxied by points for compilation dissertations) is mainly influenced by unobservables, possibly factors such as skills, supervisory expertise or supervisory involvement. All these statistical findings highlight trends which can be fully explained through detailed qualitative research. 
It is also important to highlight that more than 70 percent of all dissertations are now published in English, another clear break with the past. While this trend clearly helps the internationalization of Swedish postgraduate students, little is known about whether this helps or possibly damages their careers should they chose to leave academia- S geography has had a mation of maintaining streng links with a period of considerable societal change, the extent to which human geography can contribute fully to eurrent national and Scandinavian policy debates on urban planning, social cohesion, economic growth and inequality using the international lingua franca are currently unclear.

We believe this article is a first step towards investigating the rapid changes within the discipline in Sweden, changes which resonate with broader global themes (of gender equality and the use of English as the lingua franca within the academy) and changes which $\underline{\text { subsequent qualitative enquiry may be able offer convincing explanations for. The article has }}$ highlighted numerous avenues for further research. First, a comparison of the gendered completion rate for doctorates with the gender balance of tenured staff in departments. As a starting point, we made an attempt to investigate the academic careers of the 82 individuals that published their dissertation during the 1990s. Using the Internet and the authors' own knowledge, we were able to conclude that 27 percent of the men had made it to the rank of professor, but this share was even higher among females (36 percent). Further research is required here. Second, through reviewing the subjects of doctoral dissertations one could identify changes in the balance of sub fields within human geography. And third, to investigate the productivity of compilation dissertations through a more refined and more accurate metric (using journal impact factors or similar approaches) than the 'points' proxy we have used here. As a final remark, we hope that this research can inspire scholars to 
perform similar basic analyses of doctoral dissertations in other countries. It is the authors' firm belief that it is only through comparative research that the development of postgraduate education in human geography can be fully understood-and subsequently improved.

\section{REFERENCES}

Ahlenius, K. (1895). Olaus Magnus och hans framställning af Nordens geografi: studier $i$ geografins historia. Uppsala: Uppsala Universitet.

Asheim, B. T. (1987). A critical evaluation of postwar developments in human geography in Scandinavia. Progress in Human Geography, 11(3), 333-353.

Bauerlein, M., Gad-el-Hak, M., Grody, W., McKelvey, B. \& Trimble,Bauman, R. \& Briggs, C. L. (2000) 'Language Philosophy as Language Ideology: John Locke and Johann Gottfried Herder' in Kroskrity, P. V. (ed.) Regimes of language: Ideologies, polities, and identities. James Currey. S.W. (2010). We must stop the avalanche of low-quality research. The Chronicle of Higher Education, 13 .

Biesta, G. J. J. (2014). The Beatiful Risk of Edution. London: Paradigm.

Björkman, J. (2015). Swedish Publications in a Global World. Culture Unbound: Journal of Current Cultural Research, 7(4), 576-587.

Blom-Mondlande, U. \& Jansund, B. (2003). Geografi-Didaktik-Praktik. Interaktiva studier av förloppslandskapet. Gothenburg: University of Gothenburg.

Bourdieu, P. (1977). Outline of a Theory of Practice. Cambridge: Cambridge University Press. 
Buttimer, A. \& Mels, T. (2006). By northern lights: on the making of geography in Sweden. Burlington: Ashgate.

Canagarajah, A. S. (2003). A somewhat legitimate and very peripheral participation. In Casanave, C. P. \& Vandrick, S. (eds.) Writing for scholarly publication: Behind the scenes in language education. Routledge.

Canagarajah, A. S. (2007). Lingua franca English, multilingual communities, and language acquisition. The Modern Language Journal, 91(1), 923-939.

Dowling, R., Gorman-Murray, A., Power, E. \& Luzia, K. (2012). Critical reflections on doctoral research and supervision in Human Geography: the 'PhD by publication'. Journal of Geography in Higher Education, 36(2), 293-305.

Claeson, C. F. (1964). En korologisk publikanalys framställning av demografiska gravitations modeller med tillämpning vid omlandsbestämning på koordinatkarta. Geografiska Annaler, $46(1)$.

Elmgren, M., Forsberg, E., Lindberg-Sand, A. \& Sonesson, A. (2016). The formation of doctoral education. Lund: Lund University.

Fridlund, B. (2010). The dissertation book; Should it be a monograph or a compilation thesis? European Journal of Cardiovascular Nursing, 9(3): 144-145.

Gren, M. (2005). Forskarutbildning i kulturgeografi. Karlstad: Karlstad University Studies.

Hallencreutz, D. (2002). Populärmusik, kluster och industriell konkurrenskraft: En ekonomisk-geografisk studie av svensk musikindustri. Uppsala: Kulturgeografiska institutionen, Uppsala Universitet.

Helmfrid, S. (1962). Östergötland" Västanstång": Studien über die ältere Agrarlandschaft und ihre Genese. Geografiska Annaler, 44(1-2). 
Helmfrid, S. (1999). A hundred years of geography in Sweden. In S. Christiansen, P. Hagget, \& P, Vartiainen (Eds.). Swedish Research in Human Geography (pp. 19-54). Uppsala:

Swedish Council for Research in the Humanities and Social Sciences.

Hägerstrand, T. \& Buttimer, A. (1988). Geographers of Norden: reflections on career experiences. Lund: Lund University Press.

Jackson, D. (2013). Completing a PhD by publication: a review of Australian policy and implications for practice. Higher Education Research and Development, 32(3), 355-368.

Johnsson, B. (1965). Akerns omfattning vid 1600-talets mitt enligt de geometriska jordeböckerna: kulturgeografiska metodstudier tillämpade på Västmanlands län. Stockholm: Stockholms Universitet.

Johnston, R. \& Sidaway, J. D. (2015). Geography and Geographers: Anglo-American Human Geography Since 1945. London: Routledge.

Kabeer, N. (1999). Resources, agency, achievements: Reflections on the measurement of women's empowerment. Development and Change, 30(3), 435-464.

Kaplan, D. H. \& Mapes, J. E. (2015). Panoptic geographies: an examination of all U.S. geographic dissertations. Geographical Review, 105(1), 20-40.

Kaplan, D. H. \& Mapes, J. E. (2016). Where Are the Women? Accounting for Discrepancies in Female Doctorates in U.S. Geography. The Professional Geographer, 68(3), 427-435.

Kristoffersson, A. (1924). Landskapsbildens förändringar i norra och östra delen av Färs härad under de senaste tvåhundra åren: en kulturgeografisk studie. Lund: Lunds Universitet.

Larsen, P. O. \& Von Ins, M. (2010). The rate of growth in scientific publication and the decline in coverage provided by Science Citation Index. Scientometrics, 84(3), 575-603. 
Lee, A. (2010). When the article is the dissertation: Pedagogies for a $\mathrm{PhD}$ by publication. In Aitchison, C., Kamler, B. \& Lee, A. (Eds.) Publishing pedagogies for the doctorate and beyond (pp. 137-155). London: Routledge.

Lobell, H. (2012). Monograph or Collection of Articles with a Summary? Why?.

Forskarhandledning - introduktion, Avdelning för högskolepedagogisk utveckling, Lund: Lunds universitet.

Lundmark, M. \& Malmberg, A. (1988). Industrilokalisering $i$ Sverige: regional och strukturell förändring (No. 19). Department of Social and Economic Geography. Uppsala: Uppsala Universitet.

Lönborg, S. (1897). Adam af Bremen och hans skildring af Nordeuropas länder och folk. Uppsala: Uppsala Universitet.

Martin, G. J. (2015). American Geography and Geographers: Toward Geographical Science. New York: Oxford University Press.

Massey, D. (1994). Space, place and gender. Place: John Wiley \& Sons.

McDowell, L. (1992). Doing gender: feminism, feminists and research methods in human geography. Transactions of the Institute of British Geographers, 17(4), 399-416.

Paré, A. (2010). Slow the presses: Concerns about premature publication. In Aitchison, C., Kamler, B. \& Lee, A. (Eds.) Publishing pedagogies for the doctorate and beyond (pp. 30-46). London: Routledge.

\section{Pratt, M. L. (1991). Arts of the contact zone. Profession, 33-40.}

Peck, J. (2005). Struggling with the Creative Class. International Journal of Urban and Regional Research, 29(4), 740-770. 
Pretorius, M. (2017). Paper-based theses as the silver bullet for increased research outputs: first hear my story as a supervisor. Higher Education Research \& Development, 36(4), 823837.

Schwerin, H.H.V. (1884). Herodots framställning af Europas geografi. Lund: Lunds Universitet.

Sharmini, S., Spronken-Smith, R., Golding, C. \& Harland, T. (2015). Assessing the doctoral thesis when it includes published work. Assessment and Evaluation in Higher education, 40(1), 89-102.

SFS 1993:100 (1993). Swedish Higher Education Ordinance [Högskoleförordningen]. Stockholm: Utbildningsdepartementet.

SOU 2011:1 (2011). Svart på vitt - om jämställdhet i akademin. Betänkande av Delegationen för jämställdhet i högskolan. Stockholm: Fritzes.

Swedish Higher Education Authority [Universitetskanslersämbetet] (2016). Databas:

Doktorander och examina i högskoleutbildning på forskarnivå. http://www.scb.se/hittastatistik/statistik-efter-amne/utbildning-och-forskning/hogskolevasende/doktorander-ochexamina-i-hogskoleutbildning-pa-forskarniva/\#c_li_75815

Swedish National Agency for Higher Education [Högskoleverket] (2006). Utvärdering av grund- och forskarutbildning i kulturgeografi och grundutbildning i geografi vid svenska universitet och högskolor. Högskoleverket Rapport 2006:16 R: Stockholm: Högskoleverket.

Swedish Research Council [Vetenskapsrådet] (2006). forskarutbildningen i Sverige: Variation i volym, effektivitet och kostnader sedan tidigt 1990-tal. Stockholm: Vetenskapsrådet.

Thomson, I. (2001). Heidegger on ontological education, or: How we become what we are. Inquiry, 44(3), 243-268.

United Nations (2015). Human Development Report 2015: Work for Human Development. New York: United Nations Development Programme. 
Van Noorden, R. (2014). Global scientific output doubles every nine years. Nature News Blog.

Järngren, A. \& Ventura, F. (1977). Tre samhällens förändringshistoria: exploateringen av den fysiska miljön i historisk belysning. Statens råd för byggnadsforskning.

Wenger, E. (1998). Communities of practice: Learning, meaning, and identity. Cambridge: Cambridge University Press.

World Economic Forum (2015). The Global Gender Gap Report 2015. Geneva: World Economic Forum. 